Boise State University

ScholarWorks

$12-1-2014$

\title{
Climate Change, Water Rights, and Water Supply: The Case of Irrigated Agriculture in Idaho
}

Wenchao Xu

Xiamen University

Scott E. Lowe

Boise State University

Richard M. Adams

Oregon State University 


\section{Water Resources Research}

\section{RESEARCH ARTICLE \\ 10.1002/2013WR014696 \\ Climate change, water rights, and water supply: The case of irrigated agriculture in Idaho}

Key Points:

- Farmers' responses to water supply changes depend on their water right priority

- Climate change variations can cause substantial damages to irrigated agriculture

- Major losses (up to 32\%) are projected under future climate scenarios in Idaho

Supporting Information: - Documentation of the data and processing methods

- Supporting tables

Correspondence to:

W. Xu,

wenchaoxu@boisestate.edu

Citation:

Xu, W., S. E. Lowe, and R. M. Adams (2014), Climate change, water rights, and water supply: The case of irrigated agriculture in Idaho, Water Resour. Res., 50, 9675-9695, doi:10.1002/

2013WR014696.

Received 3 SEP 2013

Accepted 22 FEB 2014

Accepted article online 27 FEB 2014

Published online 29 DEC 2014

\author{
Wenchao Xu1 ${ }^{1}$, Scott E. Lowe ${ }^{2}$, and Richard M. Adams ${ }^{3}$ \\ ${ }^{1}$ Department of Economics, School of Economics, Xiamen University, Fujian, China, ${ }^{2}$ Department of Economics, Boise \\ State University, Boise, Idaho, USA, ${ }^{3}$ Department of Agriculture and Resource Economics, Oregon State University, \\ Corvallis, Oregon, USA
} tions such as the Prior Appropriation Doctrine.

\section{Introduction}

Abstract We conduct a hedonic analysis to estimate the response of agricultural land use to water supply information under the Prior Appropriation Doctrine by using Idaho as a case study. Our analysis includes long-term climate (weather) trends and water supply conditions as well as seasonal water supply forecasts. A farm-level panel data set, which accounts for the priority effects of water rights and controls for diversified crop mixes and rotation practices, is used. Our results indicate that farmers respond to the long-term surface and ground water conditions as well as to the seasonal water supply variations. Climate change-induced variations in climate and water supply conditions could lead to substantial damages to irrigated agriculture. We project substantial losses (up to 32\%) of the average crop revenue for major agricultural areas under future climate scenarios in Idaho. Finally, farmers demonstrate significantly varied responses given their water rights priorities, which imply that the distributional impact of climate change is sensitive to institu-

Agriculture in the arid and semiarid western United States is dependent on irrigation and is typically the largest water use. For example, in 2005, irrigation withdrawals in California, Idaho, Colorado, and Montana (combined) accounted for nearly half of the total national irrigation withdrawals and $64 \%$ of the total surface water irrigation withdrawals [Kenny et al., 2009]. Perhaps, more importantly in terms of water management, irrigation accounted for over $70 \%$ of the total water withdrawals in these four states. Water supply information, including both the long-term trends and the seasonal forecasts, therefore, is of primary importance to both irrigated farms and policy makers in these regions. As competing demands such as urbanization, industrial uses, and environmental protection have increased in recent years, water supply changes will not only influence agriculture but also these consumptive uses. For example, the Columbia Basin Water Transactions Program (CBWTP) website (http://www.cbwtp.org) has recorded a number of transactions which involve water under irrigation water rights transferred for environmental conservation, including increases to minimum flows, reductions to temperature extremes, and the flushing of sediments. Water transactions, as such, may exhibit different transaction costs. (See discussions in Garrick and Aylward [2012].) Global climate change, inter alia, will introduce more uncertainty regarding climate and future water supplies, including large warming rates [Dettinger and Cayan, 1995; Robeson, 2004; Stewart et al., 2004; IPCC, 2007] and increases in precipitation during both spring and summer [Mote, 2003a; Stewart et al., 2005; IPCC, 2007; Brown and Kipfmueller, 2012]; declining mountain snowpack [Mote, 2003b; Mote et al., 2005; IPCC, 2007; Pederson et al., 2011]; a shift in the timing of snowmelt-driven streamflow [Cayan et al., 2001; Regonda et al., 2004; Stewart et al., 2004, 2005], and a reduced amount of summer and fall streamflows [Mote et al., 2005; Stewart et al., 2005]. The increases in precipitation, therefore, may not increase the total water available to irrigated agriculture during the warm season. In addition, precipitation levels in the high-elevation mountain areas have become more variable, upon which much of the streamflow used by low elevation agricultural areas depend on during the warm season [Luce et al., 2013]. A fixed period of use, however, is assigned to irrigation water rights in Idaho, during which irrigators are allowed to divert water. Because of this, a substantial increase in the capacity of current irrigation storage facilities may be needed in order for irrigators to be able to adapt to the shift in streamflow timing. Since snowmelt from mountains is the main source of many regional water supplies [Cayan et al., 2001; Stewart et al., 2005; Bales et al., 2006; 
Mote, 2006], global climate change is expected to influence irrigation water supply, and thus to alter the irrigated agricultural landscape.

Water supply information, when analyzed in isolation, is seldom informative to water management decision making at any level. The potential value of such information depends on, and is influenced by, water institutions such as the Prior Appropriation Doctrine. This doctrine has been widely adopted as the foundation of water rights laws by most western states, thus complicating any analysis of water supply [Hutchins, 1977; Thompson, 1993; Bretsen and Hill, 2009]. Under this doctrine, a hierarchical structure of water rights priorities was established, thus forming a sequence of rights from the most senior to the most junior for any water source [Thompson, 1993]. This priority system plays a determining role in allocating regional waters. Typically, water is appropriated among competing irrigators on the basis of priority (that is, "first in time is first in right"), applied for the purpose of beneficial use (also known as, bona fide), and delivered to the land to which the water right is appurtenant, as designated in each individual water right by law [Hutchins, 1968, 1977; Thompson, 1993; Bretsen and Hill, 2009]. The principle of appurtenance of a water right to land is accepted in Idaho and other western states with a few exceptions (for example, Colorado).

In the presence of a well-functioning water market, water supply disruptions can potentially be alleviated via voluntary transfers. This is, however, not the case, at least for the State of Idaho. Both in the current literature [e.g., Thompson, 1993; Brewer et al., 2008; Hadjigeorgalis, 2009] and through personal communication with the Idaho Department of Water Resources (IDWR), the state water administrator, there are indications that market-based approaches under the prior appropriation doctrine are limited. (This was obtained through personal conversations with Michael Ciscell, Monica van Bussum, and other IDWR staff on 27 January 2011.) Idaho follows the priority principle in water appropriation and the water markets in Idaho are nascent [Hadjigeorgalis, 2009]. The Idaho law of water rights permits the sale, rental or distribution of water that is appropriated by law [The Constitution of the State of Idaho, art. XV, §§1, 2, 4, 5, 6]; however, strong institutional barriers are a major obstacle to market-based approaches in water transfers. Small-scale, market-based water transactions only occur within group water users' boundaries; in comparison, local water institutions (such as irrigation districts, canal companies, or water user associations) will prohibit water transfers between members and nonmembers. In addition, integrated water management in the presence of an uncertain water supply and competing demands will present limited opportunities to accommodate the needs of, or settle disputes among, irrigators with conflicting interests in the future. Natural factors, such as seepage, evaporation, and return flows, also present challenges for any hope of a future comprehensive water management plan.

\subsection{Objectives}

In this study, we estimate the effects of water supply signals, including the long-term supply conditions of both surface and ground waters as well as seasonal water supply forecasts, on agricultural output under the prior appropriation doctrine in a hedonic framework using Idaho as a case study (see Figure 1). The seasonal differences addressed in this study are referred to as the interannual variation (i.e., the forecast value of the total available water from one April-September growing season to another). We will not address the intraannual variation (i.e., the shifting pattern of water supply within one growing season-spring versus midsummer versus late summer). Our analysis builds upon earlier research by Schlenker et al. [2007]. Although we focus on Idaho, we employ variables that are relevant to the fundamental principles of water allocation and irrigated agricultural outcomes in the Western United States. In this study, we utilize water rights data to assist our analysis of the effects of water supply information on irrigated agricultural outcomes in the arid and semiarid U.S. West. Addressing water rights interactions among different owners such as water trading and water rights transfers, however, goes beyond the scope of this study. In addition, restricted access to data on farm-level management and cost details may pose limitations to this study as well. A different approach to address these issues can be found in He and Horbulyk [2010]. This study focuses specifically on estimating farmers' responses to water supply information and is thus different from our earlier studies [including, Xu and Lowe, 2011; Cobourn et al., 2013]. In this study, we utilize a data set that includes a broader array of farm features and agricultural water users from a different temporal range, including farms that are continuously operated and those that are not.

This article is organized as follows: section 2 reviews the literature. Section 3 discusses the data and descriptive statistics. Section 4 presents our econometric models and regression issues. Section 5 presents the 
empirical results. Section 6 projects the agricultural outputs for Idaho's major agricultural areas under future climate scenarios, and section 7 extends our discussions and concludes.

\section{Literature Review}

The current literature on the impact of climate change on U.S. agriculture focuses primarily at the national scale [for example, among others, Adams, 1989; Adams et al., 1990; Mendelsohn et al., 1994; Adams et al., 1995, 1999; Schlenker et al., 2005; Deschênes and Greenstone, 2007; Schlenker and Roberts, 2009]. While these studies analyze and project the future impact of climate change on the entire agricultural industry, regional studies can explore similar issues at a finer geographic scale, and can account for more factors with readily available data. This increased specificity generates information that is of particular relevance to policy making (see, for example, among others, Schlenker et al. [2006, 2007]; Ashenfelter and Storchmann [2010]; Ko et al. [2012]).

The impact of climate change on agriculture in the Western United States is one area of analysis that will benefit from a more regional focus. In particular, with the existence of the pro rata sharing rule and water governance structures at various levels, the impact of climate change-induced water supply variation will not be borne equally by all water users. A greater burden, therefore, will be shouldered by those (more junior) water users at the bottom of the priority system. The climate change-induced economic consequences, and ultimately the irrigated agricultural landscape, will reflect the effects of water rights under the current water regimes. Yet in the search for solutions, most discussions have overlooked the influence of water institutions and governance structures in adaptation to climate change. In the past, only a few studies have incorporated both water supply and water rights in their analyses of the impact of climate change on agriculture [e.g., Schlenker et al., 2007], largely owing to limitations of water supply data and the complicated structures of water rights priority systems.

Schlenker et al. [2007] use microlevel data to examine how surface water availability, soil characteristics, and climate variables are capitalized into farmland values and, particularly, how these values would be affected by changes in climate variables. They predict that decreases in water availability in the latest climate change scenarios downscaled to California are expected to have a significantly negative impact on farmland value. Schlenker et al. [2007] recognize the importance of incorporating water institutions, including both the effects of water rights and water supply information, into analyses of the impact of climate change on agriculture in the Western United States. They incorporate surface water availability at the district level, and find that the long-run availability of surface water is capitalized into net farmland values. They also emphasize the role of water right priorities in allocating regional water supplies; they predict that junior water right holders (hereafter, junior farmers) will face potentially larger reductions in farmland values if water availability decreases as predicted, when compared to their senior counterparts (hereafter, senior farmers).

Schlenker et al. [2007] is an important contribution to the literature on climate change, water supply, and water rights. Various aspects of their study, however, can still be improved. For example, they propose to evaluate water rights at the district level, but in practice, the priority in water use is determined by water rights at the microlevel as defined by the place-of-use requirement. Also, long-term water supply is an ex post measure of the water availability, whereas the seasonal forecast of such information could be more useful in addressing this issue. Incorporating both water rights and water supply forecasts is difficult at large geographic scales (for example, national or multistate level), considering the differences found in both water governance systems and the methodologies needed to compile water supply data between states, as well as the lack of water rights data. (For example, surface water supply data are currently compiled differently across the western states. These differences arise due to a desire to meet differential hydrological conditions and needs. This was mentioned through personal conversations with Ron Abramovich and other NRCS (Snow Survey) staff on 13 April 2011.) Nevertheless, such a study can be executed at a much smaller geographic scale.

This study examines the impact of climate change on irrigated agriculture from a regional focus by taking into account of the effects of water rights and ex ante water supplies. We make three specific contributions to the climate change-agriculture literature: first, we use both ex post information of the long-term surface and ground water supply conditions and ex ante information of the seasonal water supply forecasts to replace either average annual or seasonal values of precipitation. Average annual or seasonal values of 
precipitation are widely used in the literature but they are less feasible in arid and semiarid climate zones. Second, through a comprehensive farm-level panel data set of water rights, climate trends, water supply conditions, cropping patterns, and other farm-related variables, we are able to account for water rights priority effects in estimating an agricultural irrigator's response to water availability. The data are consolidated at the farm level, through which we also control for diversified patterns of farm-level crop mixes and rotation strategies. Third, we introduce interaction terms (between different groups of water right priority dates and seasonal water supply forecasts) to investigate the differential effects of water supply variability on farm-level economic outcomes with differing water rights portfolios (that is, different priority dates under the Prior Appropriation Doctrine).

\section{Data and Descriptive Statistics}

\subsection{Data}

We use a panel data set of water rights, cropping patterns (mixes, prices, and yields), climate (weather) conditions, and other agriculture-related variables at the farm level, as well as long-term and seasonal water supply information at the basin level. We consolidate the water rights at the farm level and isolate the priority profiles for individual farms. Three major aspects of the data are briefly described in this section, including water rights, farm-level land use features, and climate and water supply information. The details of the data, processing methods, and potential issues are discussed in the supporting information Appendix. A detailed description of the variables used in this study is presented in Tables 1 and 2.

\subsubsection{Water Rights and Farm Boundaries}

The water rights geospatial data are compiled by the IDWR and are updated regularly (last retrieved, February 2011) (IDWR, Water Rights Layers). We use the place-of-use data layer, which contains the essential aspects of the water rights, including the ownership, priority date, water source, place of use, point of diversion, water use purpose, maximum diversion rate and volume, and physical boundary. We merge the polygons in this layer in ArcGIS by ownership and construct the basic unit of this analysis-farms.

\subsubsection{Farm-Level Land Use Features}

The farm-level land use data include the water source, water right priority date, maximum diversion volume, cropping patterns, crop revenue, and soil quality for individual farms. We use a sampling strategy to create this data set by generating a uniform sampling grid, overlay the sampling grid on targeted base layers to obtain point-wise information, and consolidate the point-wise information across the state. These base layers include the Cropland Data Layer (CDL) of Idaho (2007-2011), which is used to identify the farm-level cropping patterns, the U.S. General Soil Map for Idaho which is used to evaluate soil quality, and the water rights place-of-use data which is used to determine the water source, average priority date, maximum diversion volume, and oldest water right of each farm (U.S. DoA NASS CDL, 2007-2012; U.S. DoA NRCS STATSGO2; IDWR Water Rights Layer).

\subsubsection{Climate and Water Supply Information}

Our climate data come from the PRISM Climate Group (PRISM). We use the minimum temperature in April (evaluated by both the average and standard deviation over the 1971-2000 timeframe). Our water supply information data include both the long-term (for surface and ground water supplies) and seasonal measures. Water use in Idaho can be divided into two seasons: the cold season (October of the previous year through March of the current year) and warm season (April-September). Irrigation water rights generally have a designated time of use during the warm season. In this study, we use "seasonal" instead of "annual" to avoid potential confusion over the concepts. In this case "seasonal" refers to the warm season. We use the basin-level, April-September total available water data as our ex post measure of surface water supply information. We also utilize the water level below land-surface datum (LSD) at individual irrigation wells from the Hydro Online data portal [Idaho Department of Water Resources (IDWR), Hydro Online] and obtain the current ground water level as our ex post measure of ground water supply information. We use the basin-level, April-September Water Supply Outlook Report (WSO) from the NRCS as the forecast value of seasonal water supply. The WSO forecast is provided as both a quantity and a percentage relative to a 25 or 30 year moving average of water supply conditions for the growing season (April-September). We use the percentage level in order to avoid possible collinearity with the long-term water supply measurement. We also use the county-level, annual drought emergency declaration in the previous year from the IDWR as an 
Table 1. Climate (Weather) and Water Supply Variables in the Regression Model

\begin{tabular}{|c|c|c|c|c|}
\hline Variables & Time Period(s) & Steps in Calculating Variables & Variables in Model & Sources \\
\hline \multirow[t]{3}{*}{$\begin{array}{l}\text { Long-term water } \\
\text { supply (KAF) }\end{array}$} & \multirow[t]{3}{*}{ Apr-Sep } & $\begin{array}{l}\text { 1. Average the basin-specific water sup- } \\
\text { ply data during } 1971-2000\end{array}$ & Long-term water supply-mean & \multirow{3}{*}{$\begin{array}{l}\text { U.S. Department of Agricultural, Natural } \\
\text { Resources Conservation Services (USDA } \\
\text { NRCS), Historic Monthly Adjusted } \\
\text { Streamflow [1971-2000] (http://www. } \\
\text { id.nrcs.usda.gov/snow/data/historic. } \\
\text { html\#mresv) }\end{array}$} \\
\hline & & $\begin{array}{l}\text { 2. Calculate the standard deviation of } \\
\text { the water supply for each basin ( } 27 \\
\text { basins) }\end{array}$ & $\begin{array}{l}\text { Long-term water supply-standard } \\
\text { deviation }\end{array}$ & \\
\hline & & $\begin{array}{l}\text { 3. Calculate the coefficient of variation of } \\
\text { the water supply for each basin ( } 27 \\
\text { basins) }\end{array}$ & $\begin{array}{l}\text { Long-term water supply-coefficient of } \\
\text { variation }\end{array}$ & \\
\hline \multirow[t]{3}{*}{$\begin{array}{l}\text { Short-term ground } \\
\text { water level (ft) }\end{array}$} & \multirow[t]{3}{*}{ Annual } & $\begin{array}{l}\text { 1. Compile the ground water level data } \\
\text { from the IDWR. Calculate the average } \\
\text { water level below LSD and the } \\
\text { coefficient of variation for all } \\
\text { irrigation wells with observations } \\
\text { recorded since } 2000\end{array}$ & & \multirow[t]{3}{*}{$\begin{array}{l}\text { IDWR, Hydro Online (http://www.idwr. } \\
\text { idaho.gov/hydro.online/gwl/default. } \\
\text { html) }\end{array}$} \\
\hline & & $\begin{array}{l}\text { 2. Interpolate the water levels at these } \\
\text { irrigation wells into a surface raster of } \\
\text { ground water level by using a Kriging } \\
\text { approach }\end{array}$ & $\begin{array}{l}\text { Depth to water (mean) - depth under } \\
200 \mathrm{ft} \text {; depth to water (mean)_-depth } \\
\text { over } 200 \mathrm{ft}\end{array}$ & \\
\hline & & $\begin{array}{l}\text { 3. Identify the value at the center of each } \\
\text { farm. Divide the wells into two based } \\
\text { on the average depth of the ground } \\
\text { water level and the associated } \\
\text { coefficient of variation }\end{array}$ & & \\
\hline \multirow[t]{3}{*}{$\begin{array}{l}\text { Seasonal water } \\
\text { forecast (\%) }\end{array}$} & \multirow[t]{3}{*}{ Apr-Sep } & $\begin{array}{l}\text { 1. Compile the seasonal forecast data of } \\
\text { water supply for all hydrological } \\
\text { basins }\end{array}$ & WSO & \multirow{3}{*}{$\begin{array}{l}\text { U.S. Department of Agricultural, Natural } \\
\text { Resources Conservation Services (USDA } \\
\text { NRCS), Water Supply Outlook Reports } \\
\text { [1992-2011] (http://www.id.nrcs.usda } \\
\text { gov/snow/watersupply/) }\end{array}$} \\
\hline & & $\begin{array}{l}\text { 2. Interact with the vector of indicators } \\
\text { for farmer's group with respect to the } \\
\text { oldest priority date of water right (for } \\
\text { example, Seasonal Water Forecast } \\
\text { ( } 1870 \text { and prior) stands for the } \\
\text { response to WSO for farmers with the } \\
\text { oldest water rights of } 1870 \text { or earlier) }\end{array}$ & $\begin{array}{l}\text { For example, seasonal water forecast } \\
\text { (1870 and prior), etc. }\end{array}$ & \\
\hline & & $\begin{array}{l}\text { 3. Generated a set of indicators for each } \\
\text { hydrological basin }\end{array}$ & For example, Basin SR1, Basin SR2, etc. & \\
\hline \multirow[t]{3}{*}{$\begin{array}{l}\text { Minimum } \\
\text { temperature } \\
\left(0.01^{\circ} \mathrm{C}\right)\end{array}$} & \multirow[t]{3}{*}{ Apr } & $\begin{array}{l}\text { 1. Determine the farm-specific April min- } \\
\text { imum temperature (at the centroid } \\
\text { for each farm) during } 1971-2000\end{array}$ & & \multirow[t]{3}{*}{ PRISM (http://prism.oregonstate.edu) } \\
\hline & & $\begin{array}{l}\text { 2. Averaged minimum temperature for } \\
\text { each farm during } 1971-2000\end{array}$ & $\begin{array}{l}\text { Long-term minimum temperature- } \\
\text { mean }\end{array}$ & \\
\hline & & $\begin{array}{l}\text { 3. Calculate the standard deviation of } \\
\text { the minimum temperature for each } \\
\text { farm during } 1971-2000\end{array}$ & $\begin{array}{l}\text { Long-term minimum temperature- } \\
\text { standard deviation }\end{array}$ & \\
\hline $\begin{array}{l}\text { Emergency drought } \\
\text { declaration }(0 / 1 \\
\text { indicator })\end{array}$ & Annual & $\begin{array}{l}\text { 1. Compile the county-specific data of } \\
\text { emergency drought declaration in the } \\
\text { previous season in Idaho ( } 44 \\
\text { counties) } \\
\text { 2. Interact with the vector of indicators } \\
\text { for farmer's group with respect to the } \\
\text { oldest priority date of water right (for } \\
\text { example, Drought ( } 1870-1890 \text { ) stands } \\
\text { for the response to the drought } \\
\text { emergency declaration in the } \\
\text { previous for farmers with the oldest } \\
\text { water rights of between } 1870 \text { and } \\
\text { 1890) }\end{array}$ & $\begin{array}{l}\text { For example, Drought (1870-1890), } \\
\text { Drought (1890-1910), etc. }\end{array}$ & $\begin{array}{l}\text { IDWR, Hydro Online (https://www.idwr. } \\
\text { idaho.gov/news/drought/drought. } \\
\text { htm) }\end{array}$ \\
\hline
\end{tabular}

aThe farms in the Curlew River Basin (CUR) are excluded from the analysis due to lack of data.

alternative ex ante measure for the crop years of 2007-2011 on a year-to-year basis. The summary statistics for both the ex post and ex ante water supply information are presented in Tables 3 and 4, and the spatial distribution of the water features and agricultural water uses are presented in Figure 1.

\subsection{Descriptive Statistics}

We compile a farm-level panel data set, which provides longitudinal information for the 15,767 irrigated farms identified in Idaho. Note that the identified farms are found in every county in Idaho, but the majority 
Table 2. Agriculture and Water Rights Variables in the Regression Model ${ }^{\mathrm{a}}$ Category/Variables Steps in Calculating Variables

Crop

Yield

1. Determine the crop-specific yield at the state level for each growing season all major nonfruit crops (14 crops)

Price received

Varieties

Average crop revenue (dependent variable; $\$ /$ acre)

\section{Water Rights}

Mean of priority date of water rights

Indicators of the oldest priority date of water rights

\section{Maximum diversion} volume

Water source(s)

Farm

Farm size

Soil Quality

Soil type ${ }^{c}$

Other Features

Distance to Census 2010

Urbanized Areas

Distance to major rivers and lakes
2. Determine the crop-specific price received information at the state level for each growing season all major nonfruit crops during 2002-2010

3. Generate a uniform grid of 0.1 miles and overlay this grid on the Cropland Data Layers to extract grid-wise information of crop varieties

4. Identify the crop varieties for individual farms during 2007-2011 use the indicators to represent short-term crop varieties pattern (for example, alfalfa indicates that a farm grew alfalfa during 2007-2011)

5. Calculate the weighted average of crop revenue per acre by using the crop-specific yield and price received information and the identified grid-wise crop varieties within each farm

1. Separate the irrigation water rights layer from the water rights of all other purposes of use. Remove repetitive entries and merge all water rights based on the ownership information

2. Overlay the sampling grid on the water rights place-of-use layers and extract grid-wise information of water rights

3. Calculate the mean priority date of water rights for individual farms. Identify the oldest priority date of water rights for individual farms

4. Generate a set of indicator variables of the oldest priority date of water rights for each farm (higher value of priority date means lower level of priority in appropriation. For example, a water right dated 1890 is senior to a right dated 1910)

5. Identify the maximum diversion volume for each farm by consolidating all water rights and determining the maximum value of the diversion volume for each farm

6. Identify the dominant sources of waters for each farm. Set the indicator value equal to " 1 " when the dominant source is conjunctive, and " 0 " otherwise. A similar method applies to the indicators of ground and surface water sources

1. Calculate the total number of sampling grids/ points within each farm to approximate its size

2. Generate a set of indicators for the sizes of individual farms

1. Overlay the sampling grid on the base layer of the U.S. General Soils and extract grid-wise information of soil types

2. Identify the dominant soil type for each farm based on the coverage percentage

Identify the Euclidian distance to the nearest Census 2010 Urbanized Areas for each farm in ArcGIS

Identify the Euclidian distance to the nearest major rivers and lakes for each farm in ArcGIS
For example, alfalfa, wheat, etc. (0/1 indicator)

Crop Revenue per Acre (dependent variable; \$/acre)

Mean priority date (years)

For example, 1870 and prior, etc. (0/1 indicator)

Maximum diversion volume (acre feet)

Dominant water source-ground and dominant water source-surface $(0 / 1$ indicator)

\section{Farm size}

For example, Farm (50-99 acre), Farm (100-499 acre), etc. (0/1 indicator)

Soils types $1-8^{\text {b }}$

Euclidian distance to major Census 2010 Urbanized Areas (decimal degrees)

Euclidian distance to major waters (km)
U.S. Department of Agriculture, National Agricultural Statistics Services (USDA NASS), Quick Stats of Crops and Vegetables Price Received and Yield [2003-2010] (http:// quickstats.nass.usda.gov/)

USDA NASS, Quick Stats of Crops and Vegetables Price Received and Yield [20032010] (http://quickstats.nass.usda.gov/) U.S. Department of Agriculture, National Agricultural Statistics Services (USDA NASS), Cropland Data Layer (CDL) [2007-2011] (http://datagateway.nrcs.usda.gov/)
Idaho Department of Water Resources (IDWR), Water Rights Place-of-Use Layers (http:// www.idwr.idaho.gov/Geographiclnfo/ gisdata/water_rights.htm)
U.S. Department of Agriculture, Natural Resources Conservation Services (USDA NRCS), U.S. General Soil Map (STATSGO2) (http://soildatamart.nrcs.usda.gov/)

U.S. Department of Commerce (USDC), U.S. Census Bureau [2010] (http://www2. census.gov/geo/tiger/TIGER2010/UA/ 2010/)

Idaho Department of Water Resources (IDWR), Major River and Lake Layers (http://www. idwr.idaho.gov/GeographicInfo/gisdata/ hydrography.htm)

${ }^{a}$ The farms in the Curlew River Basin (CUR) are excluded from the analysis due to lack of data.

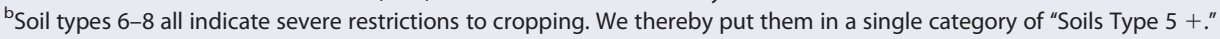

'We use a soil class method similar to Faux and Perry [1999]. We also run an additional regression by using soil type dummies and the results are similar to those found in model (1). 


\begin{tabular}{|c|c|c|c|c|c|c|c|c|c|c|c|}
\hline \multirow[b]{2}{*}{ Streams } & \multirow[b]{2}{*}{ Location } & \multirow[b]{2}{*}{ Basins } & \multicolumn{4}{|c|}{ Total Available Water (1971-2000) } & \multicolumn{5}{|c|}{ WSO (2007-2011) } \\
\hline & & & Mean & Maximum & Minimum & $S D^{b}$ & 2007 & 2008 & 2009 & 2010 & 2011 \\
\hline Bear River & Bear River at the Stewart dam & BEA & 1186 & 1791 & 528 & 365 & $47 \%$ & $68 \%$ & $53 \%$ & $17 \%$ & $162 \%$ \\
\hline Big Lost River & Big Lost River below Mackay Reservoir & BLR & 205 & 358 & 92 & 76 & $49 \%$ & $99 \%$ & $84 \%$ & $47 \%$ & $97 \%$ \\
\hline Boise River & Boise River at Boise & BOI & 2156 & 3150 & 883 & 675 & $59 \%$ & $98 \%$ & $81 \%$ & $59 \%$ & $105 \%$ \\
\hline Bruneau River & Bruneau River near Hot Spring & BRU & 219 & 631 & 44 & 122 & $52 \%$ & $89 \%$ & $100 \%$ & $58 \%$ & $154 \%$ \\
\hline Big Wood River & Big wood river below Magic reservoir & BWR & 415 & 862 & 58 & 226 & $29 \%$ & $95 \%$ & $69 \%$ & $40 \%$ & $107 \%$ \\
\hline Clearwater River & Clearwater River at Spalding & CRB & 9950 & 14,286 & 6246 & 2104 & $83 \%$ & $120 \%$ & $102 \%$ & $56 \%$ & $114 \%$ \\
\hline Henry's Fork River & $\begin{array}{l}\text { Henry's Fork near Ashton, } \\
\text { Falls River near Ashton, } \\
\text { Teton River near St. Anthony }\end{array}$ & HFB & 1907 & 2848 & 1149 & 433 & $68 \%$ & $100 \%$ & $88 \%$ & $58 \%$ & $112 \%$ \\
\hline Little Lost River & Little Lost River near Howe & LLR & 39 & 65 & 18 & 12 & $61 \%$ & $90 \%$ & $84 \%$ & $61 \%$ & $113 \%$ \\
\hline Little Wood River & Little Wood River near Carey & LWR & 113 & 219 & 35 & 52 & $36 \%$ & $102 \%$ & $81 \%$ & $46 \%$ & $103 \%$ \\
\hline Moyie River & Moyie River at Eastport & NPR & 547 & 932 & 208 & 168 & $110 \%$ & $103 \%$ & $90 \%$ & $58 \%$ & $106 \%$ \\
\hline Oakley River & Oakley Reservoir inflow & OAK & 68 & 146 & 18 & 29 & $69 \%$ & $91 \%$ & $83 \%$ & $52 \%$ & $110 \%$ \\
\hline Owyhee River & Owyhee River below Owyhee Dam & OWY & 1021 & 2503 & 242 & 412 & $33 \%$ & $88 \%$ & $70 \%$ & $56 \%$ & $148 \%$ \\
\hline Payette River & Payette River near Horseshoe Bend & PAY & 2282 & 3398 & 944 & 713 & $68 \%$ & $112 \%$ & $81 \%$ & $59 \%$ & $110 \%$ \\
\hline Salmon River & Salmon River at Whitebird & SAL & 6482 & 10,397 & 2619 & 2436 & $68 \%$ & $109 \%$ & $103 \%$ & $55 \%$ & $103 \%$ \\
\hline Salmon Falls Creek & $\begin{array}{l}\text { Salmon Falls Creek near } \\
\text { San Jacinto, Nevada }\end{array}$ & SFC & 155 & 366 & 36 & 66 & $83 \%$ & $120 \%$ & $102 \%$ & $56 \%$ & $114 \%$ \\
\hline Snake River & Snake River at Heise & $\begin{array}{c}\text { HEl, SR1, SR2, SR3, } \\
\text { SR4, SR5, CAM }\end{array}$ & 5587 & 7958 & 3467 & 1245 & $66 \%$ & $103 \%$ & $101 \%$ & $40 \%$ & $130 \%$ \\
\hline Blackfoot River ${ }^{c}$ & Snake River at Heise & BLA & 5587 & 7958 & 3467 & 1245 & $30 \%$ & $95 \%$ & $111 \%$ & $34 \%$ & $137 \%$ \\
\hline Portneuf River & Snake River at Heise & POR & 5587 & 7958 & 3467 & 1245 & $52 \%$ & $91 \%$ & $80 \%$ & $43 \%$ & $114 \%$ \\
\hline Willow River & Snake River at Heise & WIL & 5587 & 7958 & 3467 & 1245 & $30 \%$ & $89 \%$ & $93 \%$ & $30 \%$ & $154 \%$ \\
\hline Spokane River & Spokane River near Post Falls & SPO & 2821 & 5066 & 1101 & 1037 & $84 \%$ & $110 \%$ & $100 \%$ & $42 \%$ & $128 \%$ \\
\hline Weiser River & Weiser River near Weiser & WEI & 420 & 691 & 45 & 188 & $64 \%$ & $117 \%$ & $82 \%$ & $68 \%$ & $128 \%$ \\
\hline
\end{tabular}

a The unit for the total available water is KAF. The data come from the Surface Water Supply Index (SWSI) and the Water Supply Outlook (WSO), compiled by the NRCS. The total available water includes the total adjusted streamflow during the April-September growing season and the total reservoir storage at the end of March. The streamflow data do not include evaporation, transfer loss, or return flow.

${ }^{\mathrm{b}} \mathrm{SD}$ stands for the standard deviation.

'The total available water for the hydrological basins of the Blackfoot River, the Portneuf River, and the Willow River is not separately provided. Therefore, the total available water for the Snake River at Heise is used as a substitute, considering the locations of the farms.

of the irrigated farms are located in the southern sections of the state. We focus on the 6509 irrigated farms that operated continuously for the production of major, nonfruit crops in all of the years in our sample (hereafter referred to as continuously operated farms). There are several reasons that farms may not be continuously operated, such as limited natural or supplemental water supplies, production of crops other than the 14 included in this study, and lack of appropriate soil on which to grow high valued crops. Also, according to data on water banking, these noncontinuous farms are insignificant players in water transfers or leases. The inclusion of the noncontinuously operated irrigated farms will provide a broader picture of irrigated agriculture in Idaho. These noncontinuously operated farms, however, are essentially "outliers" with respect to irrigation. Therefore, we report the regression results with these farms included as model (3), but we focus on the continuously operated farms to present the empirical analysis and the projection. Compared to the remainder of the data set on farms, identified as noncontinuous, these continuously operated farms have higher crop revenues, are substantially larger in size, and provide the majority of crop output for the major crops grown in Idaho.

Table 5 presents the descriptive statistics for the irrigated farms that have been in continuous operation over the 2007-2011 timeframe, in parallel with the statistics of all identified irrigated farms. For the 6509 farms included here, the mean area is 754 acres, the mean farm-level water right priority date is 1943, the minimum priority date is 1864 (which indicates a higher priority in water appropriation) and the maximum priority date is 2008 . In terms of the dominant water source, $43.2 \%$ farms have surface water rights as their sole source; $20.1 \%$ have ground (only) water rights; and the remaining $36.7 \%$ have access to both surface and ground water sources (hereafter, conjunctive). For the weather conditions at the beginning of the growing season, the mean precipitation in April is $27.66 \mathrm{~mm}$, the maximum temperature is $15.10^{\circ} \mathrm{C}$, and the minimum temperature is $0.10^{\circ} \mathrm{C}$. The dominant soil types are Types 2 and 3 , which indicates that the soils have moderate to severe limitations which can thus limit crop choices, require special conservation practices, or both. The average distance to major rivers and lakes is $5.75 \mathrm{~km}$; the average distance to the Census 
Table 4. Summary Statistics for the Depth to Ground Water at Irrigation Wells Across Idaho: Water Level below Land-Surface Datum (LSD) (Unit: Feet)

Water Level at Individual Wells ${ }^{a}$

\begin{tabular}{|c|c|c|c|c|}
\hline Well Groups & Total \# of Wells & Mean & $S D^{b}$ & $\mathrm{CV}^{\mathrm{c}}$ \\
\hline \multicolumn{5}{|c|}{ All Irrigation Wells With Observations Collected After 2000} \\
\hline All groups & 850 & 154.50 & 5.69 & 0.04 \\
\hline (1) Depth to water $(<=0)^{d}$ & 20 & -24.27 & 3.74 & 0.22 \\
\hline (2) Depth to water (0-25) & 104 & 14.04 & 1.77 & 0.18 \\
\hline (3) Depth to water (25-50) & 129 & 37.45 & 3.37 & 0.10 \\
\hline (4) Depth to water (50-100) & 156 & 73.60 & 5.16 & 0.07 \\
\hline (5) Depth to water (100-200) & 166 & 147.30 & 6.70 & 0.05 \\
\hline (6) Depth to water (200-300) & 135 & 242.07 & 5.37 & 0.02 \\
\hline (7) Depth to water $(>300)$ & 140 & 406.48 & 10.81 & 0.03 \\
\hline \multicolumn{5}{|c|}{ Irrigation Wells with Observations Collected After 2000 (Five Observations Minimum) } \\
\hline All groups & 270 & 163.75 & 5.88 & 0.04 \\
\hline (1) Depth to water $(<=0)$ & 12 & -34.13 & 4.21 & 0.20 \\
\hline (2) Depth to water (0-25) & 25 & 16.52 & 1.92 & 0.12 \\
\hline (3) Depth to water (25-50) & 27 & 37.70 & 4.09 & 0.11 \\
\hline (4) Depth to water (50-100) & 60 & 74.64 & 5.03 & 0.07 \\
\hline (5) Depth to water (100-200) & 54 & 142.19 & 7.44 & 0.05 \\
\hline (6) Depth to water (200-300) & 40 & 242.35 & 4.59 & 0.02 \\
\hline (7) Depth to water $(>300)$ & 52 & 410.42 & 9.47 & 0.02 \\
\hline
\end{tabular}

${ }^{a}$ We first calculate the mean and standard deviation for individual irrigation wells and then the averages of these measurements within each well group.

${ }^{\mathrm{b}} \mathrm{SD}$ stands for the standard deviation.

${ }^{c} \mathrm{CV}$ stands for the coefficient of variation.

${ }^{\mathrm{d}}$ There are two reasons that the depth to ground water is negative. If its absolute value is smaller than $15 \mathrm{ft}$, this could be an artisan well. If the value is higher than $15 \mathrm{ft}$, it is likely that the casing department is placed high above the LSD, which leads to a high negative depth to ground water.

2010 Urbanized Areas is 0.95 decimal degrees. The mean crop revenues range from $\$ 608 /$ acre to $\$ 685 /$ acre during the 2007-2011 growing years. The crop revenue per acre, per farm is a nominal value without adjusting for inflation in a short duration like our study period.

In comparison, the noncontinuously operated farms differ from the continuously operated farms in three aspects. The Kolmogorov-Smirnov Test (KS-test), a nonparametric test which can determine if two data sets differ significantly, is used for our separation of continuous and noncontinuous farms. The KS-test has the advantage of making no assumption about the distribution of data. The asymptotic $p$ values for the KS-test, either evaluated in individual crop years or pooled together, are $<0.0001$, which indicate that the distributions are significantly different for the two subsamples. First, the data suggest that noncontinuously operated farms are smaller, which significantly reduces the average size of all identified farms by over half, to $\sim 359$ acres. These farms also exhibit a much higher dependency on surface water rights and a lower dependency on ground water rights. Second, noncontinuously operated farms are commonly found with a portfolio of junior water rights, in the upper reaches of minor streams, in the high-elevation mountain areas, or in Northern Idaho where farms are smaller and humid farming is more popular. On these noncontinuously operated farms, the agricultural land uses are more likely to include the production of nonmajor crops. Last, noncontinuously operated farms have a markedly uniform, lower average crop revenue per acre for those years that they are in operation, largely due to limited water resources, limited crop choices, or both. When the subsample of farms with nonoperating crop years is included in our regression analysis, we anticipate that the water rights priority effect will be greatly reduced (see Table 6, model (3)). The results support these expectations.

\section{Econometric Estimation}

\subsection{Empirical Model}

The principal challenge in assessing the impact of water supply information on farm-level economic activities is in determining how the water supply information is incorporated into the decision making of agricultural land users and the corresponding outputs. We assume that farmers are competitive and maximize their expected profits by growing multiple types of crops, that they take prices as given, and that the profits 


\begin{tabular}{|c|c|c|}
\hline & $\begin{array}{l}\text { Irrigated Farms } \\
\text { (Operated Continuously) }\end{array}$ & All Irrigated Farms \\
\hline \# of Observations & 6509 & 15,767 \\
\hline Mean farm area (acres) & 754 & 359 \\
\hline \multicolumn{3}{|l|}{ Water rights features } \\
\hline Mean priority date-Minimum & 1864 & 1862 \\
\hline Maximum & 2008 & 2009 \\
\hline Mean & 1943 & 1935 \\
\hline \multicolumn{3}{|l|}{ Water source-dominant type } \\
\hline Ground & $20.1 \%$ & $15.9 \%$ \\
\hline Surface & $43.2 \%$ & $58.9 \%$ \\
\hline Conjunctive & $36.7 \%$ & $25.2 \%$ \\
\hline \multicolumn{3}{|l|}{ Climate conditions in April } \\
\hline Precipitation $(\mathrm{mm})$ & 27.66 & 33.82 \\
\hline Maximum temperature $\left({ }^{\circ} \mathrm{C}\right)$ & 15.10 & 14.47 \\
\hline Minimum temperature $\left({ }^{\circ} \mathrm{C}\right)$ & 0.10 & -0.07 \\
\hline Soil-dominant type (Coverage $>15 \%$ ) & 2 and 3 & 2,3 , and $5+{ }^{b}$ \\
\hline Average distance to major waters $(\mathrm{km})$ & 5.75 & 5.67 \\
\hline $\begin{array}{l}\text { Average distance to Census } 2010 \\
\quad \text { Urbanized Areas (decimal degrees) }\end{array}$ & Urbanized Areas (decimal degrees) & 0.97 \\
\hline \multicolumn{3}{|l|}{ Farm per-acre crop revenue $e^{a}$} \\
\hline 2007 average (\$/acre) & 685 & $669 / 329^{c}$ \\
\hline 2008 average (\$/acre) & 625 & $598 / 334$ \\
\hline 2009 average (\$/acre) & 608 & $547 / 321$ \\
\hline 2010 average (\$/acre) & 629 & $588 / 336$ \\
\hline 2011 average (\$/acre) & 652 & $604 / 338$ \\
\hline \multicolumn{3}{|c|}{$\begin{array}{l}\text { a The average crop revenue per acre per farm is a nominal value without taking account } \\
\text { of inflation. } \\
\text { bSoil types } 6-8 \text { all indicate severe restrictions to cropping. We thereby put them in a sin- } \\
\text { gle category of "Soils Type } 5+. \text {." } \\
\text { "Zero-valued crop revenues are excluded/included, respectively, in calculating the aver- } \\
\text { ages in the "All irrigated farms" column. }\end{array}$} \\
\hline
\end{tabular}

that are derived from growing each crop are separable. We posit that when long-term water supply conditions are known, the farm-level response to water supply availability can be estimated by evaluating the relationship between seasonal water supply forecasts and subsequent land use strategies [see, for example, Iglesias et al., 2003; Peck and Adams, 2010]. Thus, farm profit $\left(\pi^{\mathrm{e}}\right)$ is a function of ex post (surface and ground) water supply $\bar{W}$, ex ante information of the seasonal water supply forecast $W^{f}$, water rights priority $V$, and other farm-specific characteristics $Z$ $\left.\left(Z=\left\{L, Z_{-}\right\}\right\}\right) . L$ is a vector of land-related factors, including farm size and soil quality. $Z_{-L}$ is a vector of additional farmspecific characteristics (for example, cropping patterns, climate, and hydrological basins).

$$
\pi^{e}=\alpha+\beta \bar{W}+\gamma W^{f}+\delta V+\zeta Z+\varepsilon
$$

$V$ represents the overall priority date in water use. A higher value of $V$ is represented by a lower value of the priority date of water rights. For example, a water right dated 1890 is senior to one that is dated 1900. It is worth nothing that the Idaho law of water rights dictates a uniform principle of priority in water use for both surface and ground water users. According to the IDWR, as of the end of 2013, the adjudication of almost all claims (including both ground and surface water rights) along the Snake River Basins has been completed, except for some water rights in the Northern Idaho sections. Almost all of the water rights in Idaho are conjunctively managed. In this study, agricultural outcomes ( $\pi^{e}$ and later $R^{e}$ ) and the seasonal water supply forecasts $\left(W^{f}\right)$ are assumed to be time-variant. Long-term climate (weather), water supply conditions, farm features (farm size, cropping patterns, and soil quality) are considered time-invariant.

Farm-specific cost data are not available, a result of the strict data limitations that arise due to growing concerns over privacy issues. For the purpose of estimation, we impose the satisficing condition of bounded rationality and replace $\pi^{e}$ with $R^{e}$ :

$$
R^{e}=\alpha_{1}+\beta_{1} \bar{W}+\gamma_{1} W^{f}+\delta_{1} V+\zeta_{1} Z+\varepsilon_{1}
$$

By doing this, we implicitly assume that the farmer has the tendency to select a revenue target as opposed to the "optimal" profit maximizing outcome. This assumption works well under the situation in which price volatility is difficult to predict, cropping decisions are irreversible, and water use fees are generally constant. Therefore, using this measure $\left(R^{e}\right)$ can significantly reduce the burden of data collection, while it still retains the essential features of profit maximization. It also fits well with a multicrop production practice, which is observed across Idaho, under which the yield measures vary between different crops and the comparison of agricultural outputs is difficult. 


\begin{tabular}{|c|c|c|c|}
\hline & OLS & 2SLS (IV) & Censored (Tobit) $)^{b}$ \\
\hline Model & $(1)$ & $(2)$ & (3) \\
\hline Intercept & $1328.205^{* * *}(143.651)$ & $1317.577^{* * *}(144.100)$ & $1164.066^{* * *}(103.980$ \\
\hline \multicolumn{4}{|l|}{ Long-Term Water Supply } \\
\hline Mean & $0.044 * * *(0.012)$ & $0.039 * * *(0.012)$ & $0.015^{* *}(0.006)$ \\
\hline Standard deviation & $-0.203^{* * *}(0.058)$ & $-0.182^{* * *}(0.057)$ & $-0.084^{* * *}(0.031)$ \\
\hline \multicolumn{4}{|l|}{ Seasonal Water Forecast } \\
\hline Priority group dated between $1870-1890$ & $-12.466(10.313)$ & $-10.330(10.333)$ & $-5.990(7.724)$ \\
\hline Priority group dated between 1890-1910 & $9.070(10.834)$ & $9.033(10.862)$ & $12.530(7.789)$ \\
\hline Priority group dated between 1910-1930 & $21.396 *(12.476)$ & 18.907 (12.478) & $22.676^{* *}(8.893)$ \\
\hline Priority group dated between 1930 and above & $23.509 * * *(8.410)$ & $22.466^{* * *}(8.433)$ & $26.009 * * *(6.563)$ \\
\hline \multicolumn{4}{|l|}{ Ground Water Use } \\
\hline \multicolumn{4}{|l|}{ Depth to water (Mean) } \\
\hline Depth under $200 \mathrm{ft}$ & $-0.237^{* * *}(0.057)$ & $-0.223^{* * *}(0.057)$ & $-0.188^{* * *}(0.043)$ \\
\hline Depth over $200 \mathrm{ft}$ & $-0.067^{* *}(0.028)$ & $-0.058^{*}(0.029)$ & $-0.036^{*}(0.021)$ \\
\hline Maximum Diversion Volume & $0.001(0.002)$ & $0.002(0.002)$ & $0.001(0.002)$ \\
\hline \multicolumn{4}{|l|}{ Long-Term Minimum Temperature } \\
\hline Mean & $0.038^{*}(0.022)$ & $0.015(0.022)$ & $0.004(0.015)$ \\
\hline Standard deviation & $-1.139 * * *(0.236)$ & $-1.130^{* * *}(0.236)$ & $-1.160^{* * *}(0.167)$ \\
\hline \multicolumn{4}{|l|}{ Water Source-Dominant Condition } \\
\hline Surface & $-26.933^{* * *}(6.453)$ & $-25.965^{* * *}(6.461)$ & $-22.340 * * *(4.911)$ \\
\hline Ground & $-2.462(7.019)$ & $-4.439 * * *(1.190)$ & $-10.035^{*}(5.550)$ \\
\hline Mean of priority date of water rights & $-4.503^{* * *}(1.187)$ & $-4.439 * * *(1.190)$ & $-2.297^{* * *}(0.864)$ \\
\hline $\begin{array}{l}\text { Mean of priority date of water } \\
\text { rights—squared adjustment term }\end{array}$ & $0.011^{* * *}(0.003)$ & $0.010 * * *(0.003)$ & $0.006^{* * *}(0.002)$ \\
\hline \# Observations & 32,545 & 32,545 & 78,835 \\
\hline Adjusted $R$-square & 0.186 & 0.185 & \\
\hline
\end{tabular}

${ }^{a}$ Robust standard errors in parentheses. ${ }^{*}$ Significant at $10 \%$ level; ${ }^{* *}$ significant at $5 \%$ level; ${ }^{* * *}$ significant at $1 \%$ level. The estimated coefficients of nonessential variables are presented in supporting information Table S6. Censored regression is performed with the lifereg procedure in SAS; Adjusted $R$-square is not reported.

${ }^{b}$ Model (3) differs from model (1) primarily in the estimated magnitudes, with the censored model estimates being significantly smaller (with the exception of the estimates of the interaction terms of the seasonal forecast). In this case, the noncontinuously operated farms face a continuous risk of water shortage. As a result, the water rights priority and long-term water conditions have relatively less of an influence on the agricultural land uses of noncontinuously operated farms than the continuously operated farms. Future research may provide more insight as to how a persistent lack of irrigation water alters the behaviors of these farmers.

If we can assume the equivalence between profit and revenue maximization when cost is somewhat fixed, an additional bridge between short-term crop productivity and its longer-term counterpart in evaluating agricultural economic activities, such as farmland value, can be established. In an efficient market, the value of land is directly related to the maximum attainable profit [Renshaw, 1958; Schlenker et al., 2007]. Given that agricultural production costs change slowly, higher revenue means higher profit and subsequently, higher land value. This makes crop revenue and farmland value equally effective in evaluating agricultural outcomes. Nevertheless, future climate change and water governance reform could introduce new factors and possibly new mechanism in determining the value of farmland.

It is possible that the construction of the dependent variable itself could be problematic. It is useful in that we are able to capture crop revenues without having to collect cost data at the farm level. If costs vary in accordance with the farm-specific characteristics (for example, farm size and location to major water sources), endogeneity will emerge as a serious issue. In order to account for this potential endogeneity, we conduct a two-stage least squares estimation (2SLS) with a set of instrumental variables (IV). We introduce additional exogenous variables to work as the instruments, which include elevation, indicator variables for agricultural zones, indicator variables of water right changes, and the mean, minimum, maximum, and standard deviation of the maximum temperature and precipitation. The results from the OLS and 2SLS regressions resemble from one another (see Table 6, models (1) and (2)); however, some estimated parameters are no longer significant in model (2) using 2SLS (for example, the estimated coefficient of April minimum temperature). In addition, we conduct the Hausman's Specification Tests over the scale effects of farm size and distance to major water sources to determine if it is necessary to use an instrumental variables approach in place of the ordinary least squares (OLS) estimation. The test results do not support that the 2 SLS approach is preferred over the OLS method at the $5 \%$ level of significance. For example, the Hausman statistic is 5.65 (degree of freedom $=56$ and $p=1.000$ ) for the regression when we examine the potential 
endogeneity issue of economies of scale that may be induced by farm size. The result indicates that 2SLS is not preferred over OLS at the $5 \%$ level of significance. Taking into account both the limitation of instrumental variables and the Hausman's Test statistics, we focus on the estimated results from the OLS method in order to obtain the projected impact in this study. For future work, or when additional instruments become available, it would be worthwhile to conduct these analyses using an instrumental variable approach, given the potential endogeneity in the specification.

\subsection{Variable Identification}

The water supply information variables $\left(\bar{W}\right.$ and $\left.W^{f}\right)$ are the main variables of interest in this study. We do not use in situ snow water equivalent (SWE) measurements to represent surface water supply. This measure consistently over- or under-represents the landscape mean of the snow depth, even though these measures are the norm at many observation sites and are used for hydroclimatological analyses and decision making [Neumann et al., 2006; Stewart, 2009]. Instead, we use the total available water over the entire April-September growing season, which includes the total (adjusted) amount of surface streamflow as well as the maximum possible carry-over from reservoir storage.

The ex post water supply information $(\bar{W})$ also includes the ground water supply. We use the depth to ground water below land-surface datum as the ground water level, which is interpolated by using the water level at irrigation wells with observations collected after 2000. The interpolated ground water level can be generated by using all irrigation wells with observations after 2000 (Table 4, top) or those wells with at least five observations after 2000 (Table 4, bottom). Note that the depth to ground water, the depth of the casing department, and the total well depth may be different. Generally speaking, the interpolated raster layers that are created by using the ground water level from both sets of wells are virtually identical. The layer generated by using ground water information from the top section has a larger geographic area, whereas the layer generated by using ground water information from the bottom section may be more reliable due to the observed fluctuation from year to year. We use the latter data in our regression analysis. The summary statistics of these wells demonstrate a pattern in which irrigation wells with higher values in the depth to ground water generally experience lower levels of volatility (see Table 4). Therefore, we distinguish the farms with ground water depths that are greater than $200 \mathrm{ft}$ from the others in the regression analysis. In addition, we use indicator variables to distinguish farmers with conjunctive water sources from those with only ground or surface water supplies and add the maximum diversion volume as a control.

The summary statistics and figures indicate that the streamflow volume measured at different times and at different locations exhibits marked variations (see Table 3 and Figure 2, respectively). Thus, the effectiveness of using the long-term total available (surface) water needs to be tested, because the estimated coefficient $\left(\beta_{1}\right)$ could be more of a reflection of the spatial heterogeneity between different basins than of the impact of long-term water supply conditions on a farmer's land-use decision making. We use a standardized measure, the coefficient of variation, to check the robustness of the regression results. In contrast, the seasonal water supply information $\left(W^{f}\right)$, which includes both the WSO and the drought emergency declaration, is standardized. (The value of the WSO ranges between 0.00 and 2.00. The value of the emergency drought declaration indicator is either 1 or 0 .) It is worth noting that the ex ante measures of seasonal water supply forecast are primarily made in terms of surface water.

To incorporate the water rights priority effects in the use of the ex ante water supply information, we generate a set of indicator variables by separating farmers based on their oldest priority date of water rights $\left(V^{\prime}\right)$. The disaggregation is arbitrarily chosen at an interval of 20 years, conforming to the major irrigation development periods in Idaho such as early settlement (1860s), reclamation under the Carey Act (1894) and the Reclamation Act (1902), the Great Depression (1930s), and the ground water development period (peaking during the 1970s). We use the Kolmogorov-Smirnov Test (KS-test) to analyze the separation of farmers into different groups based on the priority dates of their water rights portfolios. The test statistics indicate the feasibility of such a division method. The summary statistics of crop revenue (including the mean and standard deviation by different priority groups in individual crop years) as well as the KS-test statistics are presented in supporting information Table S5. We have reached the conclusion that this method of division of farmers is feasible in general, although the division of some farmers in some crop years may not work well (e.g., Priority groups (1930-1950) and (1950-1970) in the crop years of 2008 and 2010). We create an 


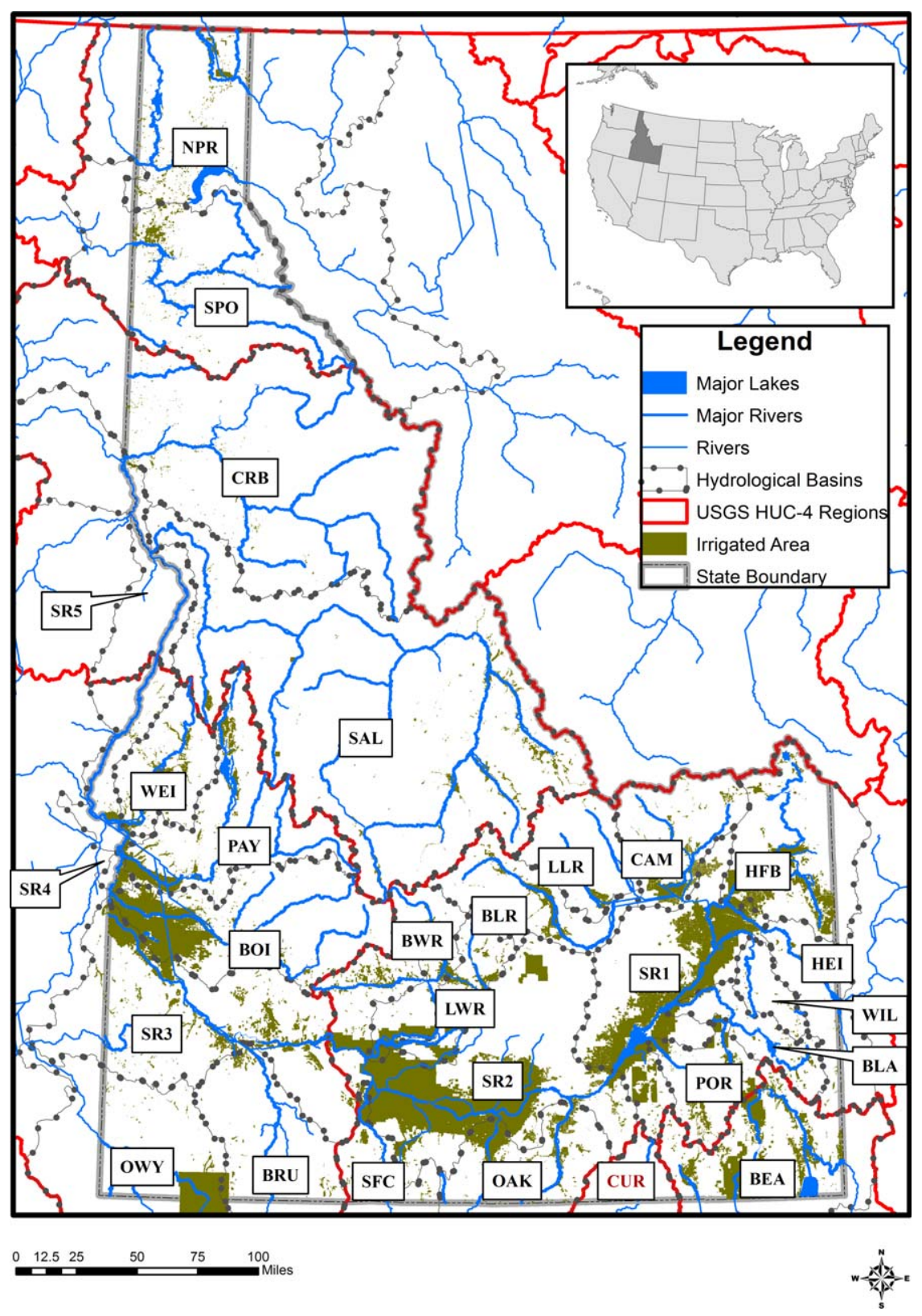

Figure 1. Spatial distribution of the water resources (major streams and lakes), hydrological basins, and irrigated agricultural land with water rights across Idaho.

interaction term $W^{f} \cdot I\left(V^{\prime}\right)$ to replace $W^{f}$ as we expect farmers with different advantages in water appropriation to respond differently to the water forecast. Our empirical model is revised accordingly:

$$
R^{e}=\alpha^{\prime}+\beta^{\prime}{ }_{1} \bar{W}+\gamma_{1}{ }_{1} W^{f} \cdot I\left(V^{\prime}\right)+\delta^{\prime}{ }_{1} V+\zeta^{\prime}{ }_{1} Z+\varepsilon^{\prime}{ }_{1}
$$

Given that some farmers hold multiple water rights and the place-of-use requirement is binding, the use of a combination of oldest priority date $\left(V^{\prime}\right)$ and mean priority date $(V)$ is preferred as it can better capture the priority effects of water rights.

The $Z$ vector contains observable farm-specific characteristics such as the climate (weather) conditions, soil quality, water source, farm size, and crop year. Of these farm-specific characteristics, it is the cropping pattern that proves to be the most essential. The cropping pattern is presented as a vector of (Bernoulli) 

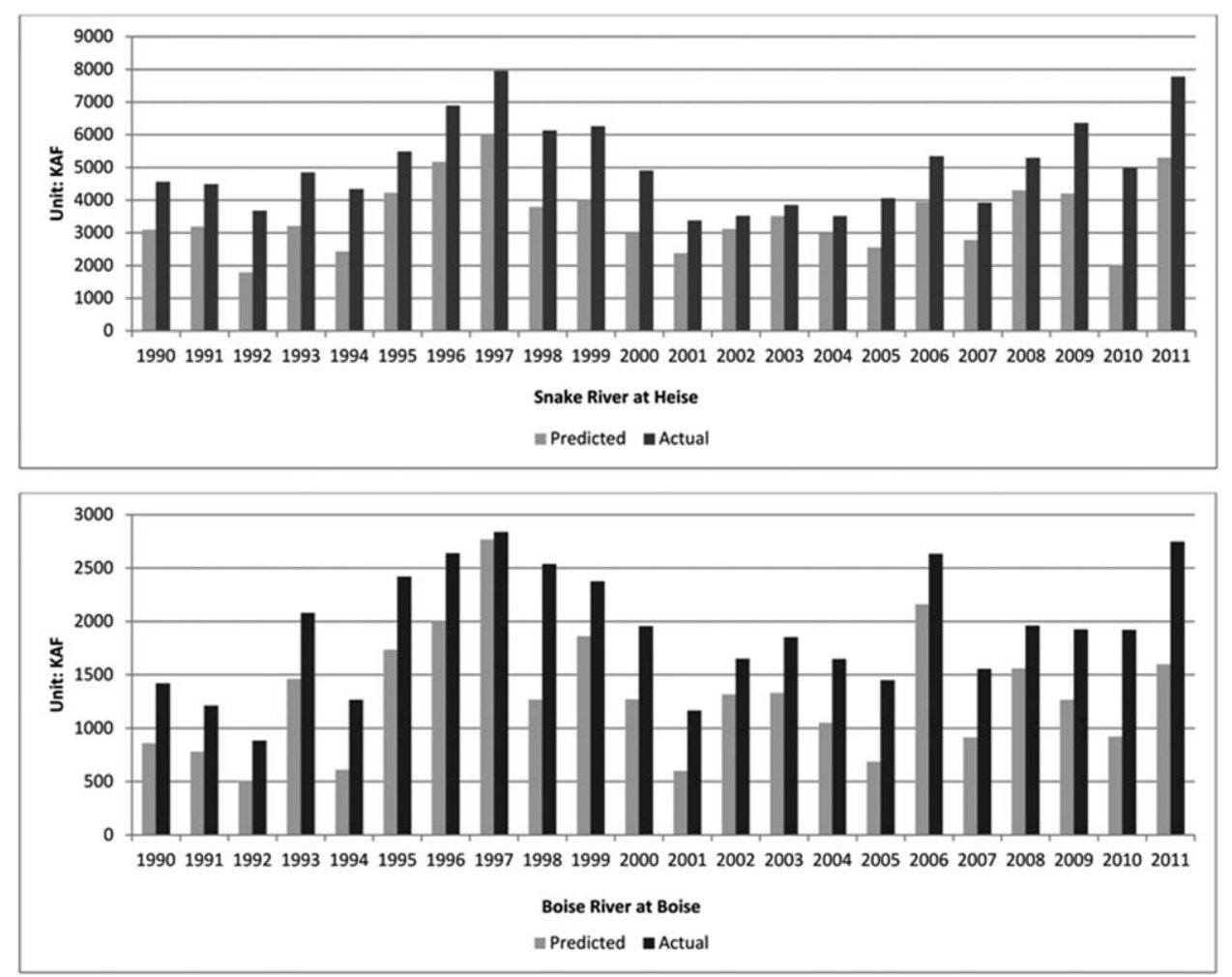

Figure 2. Historical patterns of the streamflow forecast versus the actual total available water during the April-September growing seasons: 1990-2011. (top) Snake River at Heise, (bottom) Boise River at Boise. Data sources: Surface Water Supply Index (SWSI) and Water Supply Outlook (WSO) of the NRCS Snow Survey. Units: KAF.

indicator variables over a 5 year range (2007-2011). For example, if we identify that a farm grows potatoes, wheat, and barley over the 5 year range (2007-2011), then the indicator variables for potatoes, wheat, and barley all take the value of 1 and those of the other major crops take 0 . This cropping-pattern identification method has two advantages: (1) It will pick up the complete number of crop choices in the short term and it is not prone to omitting any individual crops due to rotation practices. (2) It is a more simple identification process than using a unique indicator for each combination of crops. Alternatively, it is possible to create an indicator variable that represents the rotation pattern of potatoes-wheat-barley. Given the total availability of major crops, the set of such indicators will be large. In this case, the implications of our strategy reflect more of the bundle than of the individual crops, which may not be of as much use for policymakers. We thereby avoid any multicollinearity issues that will arise when using the crop indicators of the current year, or crop rotation issues when using the crop indicators of the previous year(s). Note that the estimated coefficients of these variables reflect not only the crops themselves, but also all of the other crops in the farmer's rotation strategy. Therefore, the cropping pattern needs to be explicitly identified for each short term period for an analysis with a long time horizon, as structural changes in irrigators' cropping strategies may occur.

There is a high correlation between the climate (weather) variables (see supporting information Tables S2S4), which severely limits the inclusion of multiple climate (weather) variables in vector $Z$. In comparison, we find that the long-term water supply and climate (weather) variables (including the minimum temperature, maximum temperature, and precipitation) do not demonstrate significant, strong correlations. This is in line with a recent study by Luce et al. [2013], who show that the changes in streamflow in the Pacific Northwest are not likely to have been caused by temperature change, but rather by decreasing precipitation in the mountains where the streams originate. Crop choices are made in the early spring and are also generally irreversible. Therefore, the cropping decision is presumed to be more associated with early growing conditions. More importantly, springtime minimum temperature is found to be representative of the multidecadal Pacific climate variability [Brown and Kipfmueller, 2012], which is in line with the focus of this study, because we use it to explain the climate variability in this region. We therefore only use the minimum 
temperature in April in our models. This approach reduces the complexity of incorporating a number of highly correlated climate (weather) variables into our empirical analysis, but still allows us to capture a broader picture of the farmer's response to various climate (weather) conditions due to the high correlation with one another. For future studies, we will also consider using long-term measures of growing degree days, similar to the measures used in Schlenker et al. [2007] and Schlenker and Roberts [2009], which may prove to be viable alternatives to control for the high levels of correlation that are found with the traditional climate (weather) variables.

\subsection{Other Regression Issues}

We estimate equation (3) in a linear regression model. Hedonic panel data analysis is prone to misspecification and omitted variable biases [Deschênes and Greenstone, 2007; Schlenker et al., 2007]. To examine the robustness of our results, we vary the modeling assumptions and use alternative sets of independent variables. (For example, we have used a set of alternative explanatory variables, which include different seasonal, short-term (5 and 10 year), and long-term (30 year) measures of climate (including precipitation, minimum, and maximum temperatures) and surface water supply variables. We have also examined different methods to consolidate farm-level priority dates and farm boundaries, as well as approaches to evaluate farm-level productivity.) In addition, we use the scatter plot of Cook's Distance to check for potentially influential observations and outliers, and we inspect the residuals plotted against the fitted values to check for heteroscedasticity. We find that some heteroscedasticity is present but not at a level that is of concern. The heteroscedasticity-consistent standard errors and $p$ values associated with the $F$ statistics do not show significant changes over the prior estimates (that is, from significance to insignificance or the reverse). The results are therefore presented without a correction for heteroscedasticity.

In addition to the potential endogeneity of farm fixed effects discussed above, endogeneity issues could also arise with respect to water sources. Because a water right is a usurfructuary right, its execution is a matter of choice, particularly when farmers have multiple water rights in their portfolios [see Schlenker et al., 2007 for a similar discussion]. As a result, it is hard to differentiate between the situation in which farmers are growing higher valued crops because conjunctive waters are available, and another situation in which the farmers employ conjunctive waters because they have planted higher valued crops. We attempt to correct for this potential endogeneity issue by including the groundwater depth and maximum diversion volume as independent variables rather than using the water source indicators alone.

\section{Empirical Analysis}

In this section, we present the estimates for the hedonic regression. We focus on the observations of all continuously operated farms during the 2007-2011 crop years. We use OLS to estimate the model specified in equation (3) for continuously operated farms, and present the results in Table 6, model (1). We present the 2SLS regression results in Table 6, model (2) to examine the endogeneity issue and cross validate the OLS results. We also use a censored regression framework as a comparison model, and present the results from this estimation in Table 6, model (3). (The censored regression analysis presented in model (3) includes all of the noncontinuously operated farms in our sample. In general, the results in model (3) are similar to those observed in model (1).) To check the robustness of our results, we conduct a series of variations to our base OLS regression model. Models (4) to (8) in Table 7 examine the influence of the spatial difference of long-term water supply conditions, the use of water right priority group indicators, the use of an alternative water supply information variable (drought declaration), the use of fixed crop revenue (versus a timevarying one), and an alternative processing method that deals with overlapping sampling points, respectively.

\subsection{Long-Term Climate and Water Supply}

The findings in model (1) of Table 6 indicate that a $1{ }^{\circ} \mathrm{C}$ increase in the minimum temperature in April increases the average crop revenue by $\$ 3.8 /$ acre $(\sim 0.038)$, which is statistically significant, and is in line with earlier studies [e.g., Mendelsohn et al., 1994; Deschênes and Greenstone, 2007]. (Note that we keep the minimum temperature in the unit used by the PRISM, measured in $0.01^{\circ} \mathrm{C}$. The numbers in the parenthesis are the estimated coefficient values from the tables.) Irrigated farmers respond to climatic variation as well. A $1{ }^{\circ} \mathrm{C}$ increase in the standard deviation of the minimum temperature in April substantially decreases the 


\begin{tabular}{|c|c|c|c|c|c|}
\hline Model & (4) & (5) & (6) & (7) & (8) \\
\hline Intercept & $1401.805^{* * *}(144.388)$ & $1388.715^{* * *}(169.591)$ & $1189.732^{* * *}(135.200)$ & $1475.308^{* * *}(170.578)$ & $1176.916^{* * *}(140.017)$ \\
\hline \multicolumn{6}{|l|}{ Long-Term Water Supply } \\
\hline Mean & & $0.045^{* * *}(0.012)$ & $0.043^{* * *}(0.012)$ & $0.047^{* * *}(0.014)$ & $0.047^{* * *}(0.012)$ \\
\hline Standard deviation & & $-0.203^{* * *}(0.058)$ & $-0.194^{* * *}(0.057)$ & $-0.220^{* * *}(0.068)$ & $-0.212^{* * *}(0.056)$ \\
\hline Coefficient of variation & $-269.021^{* * *}(43.650)$ & & & & \\
\hline \multicolumn{6}{|l|}{ Seasonal Water Forecast } \\
\hline Priority group dated between $1870-1890$ & $-7.220(10.277)$ & $-13.057(9.991)$ & & $10.120(12.246)$ & $-14.185(10.055)$ \\
\hline Priority group dated between $1890-1910$ & $10.575(10.813)$ & $10.532(10.743)$ & - & $40.138^{* * *}(12.864)$ & 9.049 (10.624) \\
\hline Priority group dated between $1910-1930$ & $20.312(12.473)$ & $24.486 *(12.570)$ & - & $52.930 * * *(14.815)$ & $17.568(12.325)$ \\
\hline Priority group dated 1930 and above & $22.112^{* * *}(8.410)$ & & - & $70.092^{* * *}(9.987)$ & $22.187^{* * *}(8.342)$ \\
\hline Priority group dated between $1930-1950$ & & $24.449 * *(10.764)$ & - & - & - \\
\hline Priority group dated between $1950-1970$ & & $33.993^{* * *}(9.100)$ & - & - & - \\
\hline Priority group dated 1970 and above & & $28.007^{* *}(11.650)$ & - & - & - \\
\hline \multicolumn{6}{|l|}{ Emergency Drought Declaration } \\
\hline Priority group dated 1910 and prior & - & - & $-8.441(9.546)$ & - & - \\
\hline Priority group dated between $1910-1930$ & - & - & $-14.290(25.210)$ & - & - \\
\hline Priority group dated between $1930-1950$ & - & - & $-8.164(19.932)$ & - & - \\
\hline Priority group dated after 1950 & - & - & $-23.651^{* *}(9.916)$ & - & - \\
\hline \multicolumn{6}{|l|}{ Ground Water Use } \\
\hline \multicolumn{6}{|l|}{ Depth to water (mean) } \\
\hline Depth under $200 \mathrm{ft}$ & $-0.214 * * *(0.056)$ & $-0.241^{* * *}(0.057)$ & $-0.242^{* * *}(0.057)$ & $-0.271^{* * *}(0.067)$ & $-0.238^{* * *}(0.056)$ \\
\hline Depth over $200 \mathrm{ft}$ & $-0.068^{* *}(0.028)$ & $-0.071^{* *}(0.029)$ & $-0.065^{* *}(0.028)$ & $-0.078^{* *}(0.034)$ & $-0.063^{* *}(0.028)$ \\
\hline Maximum Diversion Volume & $0.001(0.002)$ & $0.001(0.002)$ & $0.001(0.002)$ & $-0.271^{* * *}(0.067)$ & $0.003^{*}(0.002)$ \\
\hline \multicolumn{6}{|l|}{ Long-Term Minimum Temperature } \\
\hline Mean & $0.063^{* * *}(0.022)$ & $0.037^{*}(0.022)$ & $0.038^{*}(0.022)$ & $0.001(0.002)$ & $0.031(0.022)$ \\
\hline Standard deviation & $-1.128^{* * *}(0.234)$ & $-1.130 * * *(0.236)$ & $-1.106^{* * *}(0.235)$ & $0.058^{* *}(0.026)$ & $-1.101^{* * *}(0.233)$ \\
\hline \multicolumn{6}{|l|}{ Water Source-Dominant Condition } \\
\hline Surface & $-29.097^{* * *}(6.408)$ & $-27.567^{* * *}(6.457)$ & $-25.026^{* * *}(6.431)$ & $-37.443^{* * *}(7.662)$ & $-32.788^{* * *}(6.178)$ \\
\hline Ground & $-0.947(7.016)$ & $-3.382(7.063)$ & $0.219(7.003)$ & $-4.783(8.334)$ & $-0.922(6.995)$ \\
\hline Mean of priority date of water rights & $-4.682^{* * *}(1.186)$ & $-4.981 * * *(1.464)$ & $-3.510^{* * *}(1.128)$ & $-4.855^{* * *}(1.409)$ & $-3.064^{* * *}(1.163)$ \\
\hline $\begin{array}{l}\text { Mean of priority date of water } \\
\text { rights-Squared adjustment term }\end{array}$ & $0.011^{* * *}(0.003)$ & $0.011^{* * *}(0.003)$ & $0.009 * * *(0.002)$ & $0.011^{* * *}(0.003)$ & $0.007^{* * *}(0.002)$ \\
\hline \# Observations: & 32,545 & 32,545 & 32,545 & 32,545 & 32,545 \\
\hline Adjusted $R$-square & 0.187 & 0.186 & 0.186 & 0.173 & 0.183 \\
\hline
\end{tabular}

${ }^{a}$ Robust standard errors in parentheses. ${ }^{*}$, significant at $10 \%$ level; ${ }^{* *}$, significant at $5 \%$ level; ${ }^{* * *}$, significant at $1 \%$ level. The estimated coefficients of nonessential variables are presented in supporting information Table S7.

average crop revenue by $\sim \$ 113.9$ /acre $(-1.139)$, or $\sim 18 \%$ of the current average crop revenue for the crop years from 2007 to 2011 . These findings suggest that the combined impact of future climate change will not only be determined by the magnitudes of these two contrary effects, but also by the relative changes of the two factors. If future climate change induces only moderate increases in temperature but with relatively greater volatility, then the negative impact on irrigated agriculture will dominate.

The estimated impact of the long-term surface water supply measures demonstrate similar patterns to those of the minimum temperature effects. A 1 million acre feet (MAF) increase in the average adjusted streamflow will increase the average crop revenue by $\sim \$ 44 /$ acre $(0.044)$, or $\sim 7 \%$. This finding is consistent with the impact of water supply on average farmland values presented in Schlenker et al. [2007], although the difference in magnitude is a result of different measurements in economic activities. Similar to temperature, increased surface water supply volatility will adversely impact crop revenues as well. A 1 MAF increase in the standard deviation of water supply volatility will reduce the average crop revenue by $\sim \$ 203 /$ acre $(-0.203)$ or $\sim 32 \%$. We assume a $1 \mathrm{MAF}$ standard deviation because the majority of the identified farms in our sample are located in the hydrological basins along the Snake River ( 49\%) where the long-term standard deviation of the total available water is 1.245 MAF (see Table 3). The Boise River and the Henry's Fork River, which have an approximately equally significant portion of the farms in our sample, have similar magnitudes in standard deviations. Again, the combined effects appear to depend on both the level and variability of water supply under the future climate scenarios. Overall, the implied impacts of climate and water supply variability are striking. We postulate that it is a lack of flexibility on the part of irrigators that is the main reason for this outcome. Without a statewide, mature market for water transactions, agricultural irrigators, particularly the junior water rights holders, are likely to be unable to secure water for their high-valued and water-intensive crops during low water years. To overcome the volatility issue in these areas, more land 
will be planted in drought-tolerant and lower-valued crops, which will subsequently lower the average crop revenue.

Irrigated farmers are found to be sensitive to changes in ground water levels as well. A 1 foot increase in the ground water depth will negatively impact the crop revenues for both farmers with shallow $(<200 \mathrm{ft})$ and deep ground water resources $(>=200 \mathrm{ft}$ ), by $\$ 0.24$ /acre (or $\sim 0.04 \%$ ) and $\$ 0.06 /$ acre (or $\sim 0.01 \%$ ), respectively. This finding is consistent with the estimates reported in Schlenker et al. [2007], where the same increase in the depth to ground water decreases farmland value by $\$ 1.47 /$ acre or $\sim 0.04 \%$. In addition, the average crop revenues for the irrigated farmers with surface-only water sources are significantly lower than the revenues of those irrigators with conjunctive water sources, by $\sim 29.10 /$ acre $(-29.097)$, whereas the difference in the average crop revenue between farmers with ground-only and conjunctive sources are small and not significantly different from one another. We do not find that the maximum diversion volume has a significant effect on crop revenue. This is not surprising: it is nearly impossible to reach the appropriated maximum for the majority of irrigated farmers when water is scarce. Ideally, we would use actual farmlevel diversion data in place of the maximum diversion volume, but water diversion data for individual farms are generally not available due to privacy concerns.

To address the concern over the spatial differences in the long-term water supply conditions between basins, we use the coefficient of variation to replace the combination of mean and standard deviation for the long-term water supply conditions (see Table 7, model (4)). We find that a $10 \%$ increase in water supply volatility, when standardized, would result in a substantial reduction in crop revenue by $\sim \$ 26.90 /$ acre $(-269.021)$.

\subsection{Seasonal Water Supply Information}

Using the seasonal water supply values, as opposed to long-term trends, in assessing the farmers' responses to the observed or expected climate situation is a better reflection of their adaptation strategies. We hypothesize, ceteris paribus, that a farmer's water rights portfolio will influence her response to seasonal water supply variations. In Table 6, model (1), we present four interaction terms between the period of water rights priorities and the water supply forecast: 1870-1890, 1890-1910, 1910-1930, and 1930+. Our estimates corroborate our hypothesis: for farmers with the most junior water rights (in this case, farmers with a mean water right priority date of 1930 or younger, based on the state average), a 10\% increase in the water supply forecast will lead to a modest gain in average crop revenue of $\sim \$ 2.35 /$ acre.

It is notable, however, that the estimated coefficients of these interaction terms are small. We believe that there are several contributing factors. First, the water supply predictions that farmers utilize are sophisticated. For example, both the historic patterns of water supply and the seasonal conditions in snowpack, precipitation, radiation, and other relevant factors need to be considered. Different weighing methods that are applied to these factors could result in significantly varied projections or even lead to departures from the observed water supply (as Figure 2 shows). Second, anthropogenic factors play an important role in influencing seasonal water allocations. Under the current water regime, local irrigation water is allocated based on the priority principle. Water management could substantially change the allocation too, but such an adjustment by upstream water managers is difficult to predict by downstream farmers. This means that a nominal increase in the total water supply will not result in an observable change at the farm level. This is particularly challenging for farmers with junior water rights. In this case, even though they stand to gain the most from additional water supply, it is likely that their total available water will not increase at all. In spite of the aim to stabilize water supplies, it is the anthropogenic, institutional factors, in parallel with other environmental features, that increase the uncertainty surrounding water supply and curtailment risk for the farmers at the bottom of the water rights hierarchy who frequently suffer from water shortage.

Compared to the most junior water rights holders, the farmers in the middle tiers exhibit a markedly different response: a 10\% increase in the water supply forecast results in a smaller, often insignificant increase in the average crop revenue (for example, $\sim \$ 0.91 /$ acre and $\sim \$ 2.14 /$ acre). These results suggest that farmers with the more senior water rights will not respond to an incremental water supply change. This result is in line with our expectations: farmers with the more senior water rights generally experience less frequent irrigation water curtailment than the junior water users. The actual reason for this outcome, however, is rooted in Idaho's water rights law. The law requires that every water right in Idaho be identified with the exact water source, application location, and maximum quantity (or volume). The law also prevents appropriators 
from using any excess water on land parcels that do not have any water rights appurtenant to them, under the principles of the appurtenance of a water right to land and beneficial use. The combination of both principles will prohibit these farmers from using the added supply of water on their own lands. In addition, local water institutions are generally strongly opinioned in prioritizing local appropriators' interests, which severely limits trans-boundary water transfers [Thompson, 1993]. The lack of a mature water market to conserve and sell any excess water supplies has contributed to these lowered incentives.

Given these seemingly counterintuitive results, it should not be surprising that the most senior water rights holders experience a negative response to increased water supply forecasts, relative to the average response. For these irrigators, a $10 \%$ increase in the water supply forecast reduces their average crop revenues by $\sim \$ 1.25 /$ acre. Compared to the other farmers who possess water rights that were established in the 20th century (when many major irrigation projects were constructed), the more senior water rights holders are associated with lands that are in close proximity to the major rivers or are in the high elevation, mountain areas, which largely result from the early settlers' path of migration and settlement. For these farmers, increased water supplies could create drainage issues and reduce crop productivities. In addition, demand elasticity matters. If increased water supplies result in increased outputs for the more junior farmers, market forces will affect the local prices that all irrigated farmers receive due to increased supply, and therefore adversely impact the incentives of growing high-valued crops for these farmers. We find that unlike corn and small grains, the high-valued, water-intensive crops like potatoes, sugarbeets, onions, and alfalfa have high transportation costs due to their weights, and thus are infrequently shipped to distant processing facilities. When the available water supply increases, the local markets for these crops may experience excess supply. This could drive down prices and reduce the incentives to grow these crops in the next growing season.

By differentiating the response function to the ex ante water supply information by the water rights priority date, we reach similar conclusions to those of Schlenker et al. [2007]. Compared to the senior water users, farmers with junior water rights will face potentially significant reductions in water availability during drought periods, and thus, suffer potentially substantive losses. This implies that the burden of future climate change could be borne disproportionately by junior farmers. Even though California and Idaho have different water uses, water rights laws, and future climate change scenarios, the water rights priority system generates similar outcomes with respect to the more and less impacted groups based on their water rights portfolios (that is, senior versus junior farmers).

We add the average priority date and its square term to our regression models in order to control for the influence of the water right priority on crop revenue. The estimated coefficients indicate that there is a strong negative correlation between crop revenue and the water rights priority date, which corroborates our argument that higher water right priority results in greater economic returns in irrigated agriculture.

\subsection{Additional Robustness Checks}

In addition to the robustness tests mentioned above, we conduct a robustness check with the expanded water rights priority groups (as in Table 7, model (5)) and another one with an alternative water supply indicator (that is, the drought emergency declaration) to further examine the hypothesis of heterogeneous responses to water supply conditions (as in Table 7, model (6)). We replace the fixed crop revenue measure with time-varying crop prices and yields (as in Table 7, model (7)). In addition, we introduce an alternative processing method that deals with overlapping sampling points (as in Table 7, model (8)). That is, we assign overlapping sampling points to the farm with the oldest priority date. Overlapping boundaries of water rights is not only a technical matter in creating geospatial maps, but a result of property ownership between farmers with conflicting interests. In all of the robustness tests noted above, we are unable to find significant evidence that differs from the findings from model (1).

\section{Potential Future Climate Change Impact on Crop Revenue}

Given the estimated coefficients presented above, we briefly speculate on the potential impact of climate change on agricultural outcomes in Idaho. We should note that our projections are not definitive, as additional data are needed on farm boundaries, operating expenses, crop prices and water deliveries, as well as detailed projections of climate and water supply conditions. Nonetheless, these projections give some 
insight as to the impact of climate change on agriculture in Idaho and in other similarly arid and semiarid regions.

Climatologists and hydrologists have observed a large warming trend in most of the Western United States, and they anticipate that this trend will persist. Temperatures are projected to rise by $1.1-2.9^{\circ} \mathrm{C}$ over the Western United States by the end of the 21 st century [Mote and Salathé, 2010]. The most significant impact of this general warming was found to be a large reduction in mountain snowpack and a substantial shift in streamflow seasonality [Barnett et al., 2005]. Reduced flow in June and increased flow in March [Stewart et al., 2005], and reduced spring snow water equivalent [Mote, 2003a; Mote et al., 2005] are anticipated. A study by Elsner et al. [2010] projects that the runoff in Washington during the growing season (from April to September) will decrease by $16.4-19.8 \%$ by the 2020 s, $23-29.6 \%$ by the 2040 s, and $34.4-44.2 \%$ by the 2080s.

To estimate the potential impact of climate change on agriculture, we need the mean and standard deviation of both temperature and water supply conditions. We use the temperature projection of Mote and Salathé [2010] and the runoff projection of Elsner et al. [2010]. The runoff projection covers a large portion of the Columbia River Basin, of which the Snake River Basin is the largest tributary and the most important agricultural area in Idaho. A detailed projection of the standard deviation of temperature or streamflow is unavailable for this area. We use the projected range of -0.5 to $1.0^{\circ} \mathrm{C}$ for temperature extremes from the IPCC [2007]. We also use the observed historic pattern of streamflow volatility and assume an increase of $5 \%$ in the standard deviation [Dittmer, 2013].

We assume that carbon emissions, land use, water trading, and crop prices are held constant. We also assume that the ground water level remains unchanged and that the standard deviation of water supply is consistent with the observations from the past 100 years. For the continuously operated farms that produce major crops in the most productive region of the East Snake River Plain area (which is roughly the combined area of SR1 and SR2), we project that the average crop revenue in the short-term (by 2020) could experience a very small loss or gain (around $-\$ 0.56$ /acre to $\$ 7.04 /$ acre, or $-0.1 \%$ to $1.0 \%$ ). This scenario assumes that the minimum temperature in April increases by $1^{\circ} \mathrm{C}$ from its current level and its standard deviation decreases by $0.5^{\circ} \mathrm{C}$ or increases by $1^{\circ} \mathrm{C}$, and the total available water decreases by $\sim 20.0 \%$ (that is, 1106.24 KAF) and its standard deviation increases by 5\% (that is, $62.27 \mathrm{KAF}$ ) (see supporting information Table S8). The 2007-2011 average crop revenues in the East Snake River Plain area are $\sim \$ 730 /$ acre for continuously operated irrigated farms and $\sim \$ 581$ /acre for all irrigated farms. The potential gain is primarily attributed to the temperature increase, whereas the losses are a combined result of the reduction in water supply and the increase in climate and surface water supply volatility. If the surface water supply is further reduced by $44.2 \%$ by 2080 , as Elsner et al. [2010] project, the losses could reach $\$ 231.40 /$ acre even when the increase in the minimum temperature and the volatility levels remain unchanged from the previous scenario. In this case, the reduction in water supplies would result in a loss in revenues by up to $\sim 32.0 \%$. This value is consistent with the projected loss in farmland value by up to $40.7 \%$ found in Schlenker et al. [2007]. (Schlenker et al. [2007] found that the most recent climate change scenarios downscaled to California would result in damages to farmland values by as much as $\$ 1700 /$ acre. The average farmland value in their sample is $\$ 4177 /$ acre.)

\section{Discussion and Concluding Remarks}

This study estimates the impact of climate change-driven water supply variations and water rights on agricultural outputs in Idaho by using a large panel data set of microdata. We analyze irrigators' responses to long-term and seasonal water supply signals. Sensitivity analyses are conducted in order to address various issues regarding alternative model specification, data, and processing strategies. Future climate projections are utilized to simulate the impact of future climate scenarios on agricultural outcomes for Idaho's major agricultural areas.

There are several important implications of our findings. First, climate change will impact a farmer's land use decision and thus, the future agricultural landscape when the force of such a change works collectively on large geographic scales. We expect a warming trend with increased surface water supply to increase the economic performance of farm operations. However, if future climate change introduces more volatility in temperature and water supply, substantial losses to agriculture are anticipated (by up to 32\%). Second, our 
empirical results suggest that water rights have significant effects on farm-level economic activities. The priority in water appropriation, determined by the priority date of a water right or a portfolio of numerous water rights, is captured and reflected in agricultural outputs. The priority effect varies with respect to the source of the water that is designated in individual rights. This effect, moreover, reflects a farmer's adaptation strategy to natural conditions and institutional barriers, when diversified patterns of crops are used. Third, farmers respond to seasonal water supply information in varied ways. Nonuniform water right portfolios and the hierarchical structure of water rights institutions influence the differential responses to seasonal water supply. Specifically, junior water users are more sensitive to the impact of any changes in climate or water supply conditions than are more senior irrigators.

As noted, our simulation assumes that the pattern of land use is held constant. It is possible that future potential land use changes could be induced by climate change. In some places, irrigation storage facilities could be expanded such that they receive more streamflow during the winter and early spring seasons and transfer it to irrigation during the irrigation season. In comparison, in other locations, particularly those in the high-elevation mountain areas, the impact of climate change will be more severe when the water supply decreases substantially during the growing season and it is not economically efficient to expand current irrigation facilities. In this case, there will be an increased idling or abandonment of irrigated land in these areas. As water demands from competing uses increase in the face of severe future water shortages, the need for cooperation will become paramount.

In addition to irrigation improvements that reduce problems such as seepage, evaporation, or other transport losses, there are a number of potential ways to mitigate the impact of climate change on irrigated agriculture in the arid and semiarid regions like Idaho. Ground water is a potentially more reliable source and could thus be used by farmers as a buffer against any shortfalls in surface water deliveries. But the use of ground water to mitigate the impact of future climate change is subject to a number of major constraints, each of which increases the uncertainty: (1) Ground water levels decline over time. An analysis of the depth of the irrigation wells in our sample indicates that declines have already occurred at various spatialtemporal scales (see supporting information Table 59). (2) Ground and surface waters interact. In Idaho, specifically for the Snake River Aquifer, surface and ground waters are conjunctively managed, and the ground water levels can be significantly impacted by changes in surface waters. A substantial decline in surface water supply, as is projected in many of the climate change scenarios, will exacerbate the decline in ground water levels as well. (3) Not all farms have access to ground water, both geographically and in a legal sense. Like many western states, Idaho water rights law upholds the "no-injury" rule in establishing new water rights, confirming changes to existing water rights, or approving transboundary water transactions. The noinjury rule states that appropriative rights can be changed, provided that the change does not cause an injury to any other rights [Hutchins, 1977]. The no-injury rule can be found in many statues of the Idaho law of water rights (for example, Idaho Code sections 42-201, $-222 \mathrm{~A},-1426$, and -1701 ). This is the basic principle in assessing water rights changes and transboundary water transactions in this State. Existing appropriators with ground water rights will block such transactions, particularly when water resources become more scarce.

Another way to mitigate the impact of future climate change is to increase the number of water transactions and to introduce more market-based approaches to the present structure of water governance. Since it was established in the early 1930s, Idaho's regional water supply bank, a prototype market which allows farmers to lease and rent water, has grown in recent years. According to the IDWR, since 2005, a total of 1084 water rights in lease applications and 266 in rental applications have been recorded. The water rights under these submissions account for $0.6 \%$ and $2.3 \%$, respectively, of the total irrigation water rights held in the state. The percentages are calculated based on the total number of water rights involved in water banking since 2005 and the total number of irrigation water rights identified from the water rights place-of-use layer. The data suggest that these leasing and rental activities in Idaho have not significantly influenced the allocation of regional waters. Anecdotal evidence indicates that the primary purpose of Idaho's regional water supply banks is to maintain idle water rights and to fulfill the beneficial use principle, as opposed to promoting market-based water transactions. Market-based approaches, therefore, have a limited influence. In order to mitigate the impact of climate change, future policies will need to consider economic incentives to promote water transactions, increase water use efficiency, and reduce potential losses. 


\section{QAGU Water Resources Research}

Our findings are subject to several caveats. First, we are unable to observe irrigation technologies, farm operating expenses, and $\mathrm{CO}_{2}$ fertilization. Our approach does not capture possible (future) water transfers between farmers and thus it cannot fully capture the farm-level management of water supply that will occur if water is in short supply. Second, our projection of agricultural outcomes under future climate scenarios does not consider any market-based water transactions or improvements in water storage facilities that will influence water use efficiencies or cropping costs. Last, there is also a need for more fine-scale data of crop prices and yields, and long-term and seasonal water supply conditions.

\section{Acknowledgments}

Lowe received financial support for this study under a grant from the NSF Idaho EPSCOR Program and by the National Science Foundation (grant EPS-0814387). The authors wish to thank Ximing Cai, three anonymous reviewers of this Journal, and Man $\mathrm{Li}$ for their constructive comments and suggestions. Thanks are also due to Michael Ciscell, Ron Abramovich, and David Hoekema for their help and assistance with the data and background information. The authors also wish to thank Jeff Anderson, Richard G. Allen, Monica van Bussum, Peter Cooper, Shelley Keen, Don W. Morishita, Howard Neibling, Tony Olenichak, and other staff from the Idaho Department of Water Resources (IDWR), the USDA, Natural Resources Conservation Service (NRCS), Snow Survey, the University of Idaho, and Idaho National Laboratory (INL). Any opinions, findings, and conclusions or recommendations expressed in this material are those of the authors and do not necessarily reflect the views of the individuals or agencies list above.

\section{References}

Adams, R. M. (1989), Global climate change and agriculture: An economic perspective, Am. J. Agric. Econ., 71(5), $1272-1279$.

Adams, R. M., C. Rosenzweig, R. M. Peart, J. T. Ritchie, B. A. McCarl, J. D. Glyer, R. B. Curry, J. W. Jones, K. J. Boote, and L. H. Allen Jr. (1990), Global climate change and US agriculture, Nature, 345(6272), 219-224.

Adams, R. M., R. A. Fleming, C.-C. Chang, B. A. McCarl, and C. Rosenzweig (1995), A reassessment of the economic effects of global climate change on U.S. agriculture, Clim. Change, 30(2), 147-167.

Adams, R. M., B. A. McCarl, K. Segerson, C. Rosenzweig, K. J. Bryant, B. L. Dixon, R. Corner, R. E. Evenson, and D. Ojima (1999) Economic effects of climate change on US agriculture, in The Impact of Climate Change on the United States Economy, edited by R. Mendelsohn and J. E. Neumann, pp. 18-54, Cambridge Univ. Press, Cambridge, Mass.

Ashenfelter, O., and K. Storchmann (2010), Using hedonic models of solar radiation and weather to assess the economic effect of climate change: The case of Mosel Valley vineyards, Rev. Econ. Stat., 92(2), 333-349.

Bales, R. C., N. P. Molotch, T. H. Painter, M. D. Dettinger, R. Rice, and J. Dozier (2006), Mountain hydrology of the Eastern United States, Water Resour. Res., 42, W08432, doi:10.1029/2005WR004387.

Barnett, T. P., J. C. Adam, and D. P. Lettenmaier (2005), Potential impacts of a warming climate on water availability in snow-dominated regions, Nature, 438(7066), 303-309.

Bretsen, S. N., and P. J. Hill (2009), Water markets as a tragedy of the anticommons, William Mary Environ. Law Policy Rev., 33(3), $723-783$.

Brewer, J., R. Glennon, A. Ker, and G. Libecap (2008), 2006 presidential address: Water markets in the West: Prices, trading, and contractual forms, Econ. Inquiry, 46(2), 91-112.

Brown, D. P., and K. F. Kipfmueller (2012), Pacific climate forcing of multidecadal springtime minimum temperature variability in the Western United States, Ann. Assoc. Am. Geogr., 102(2), 521-530.

Cayan, S., A. Kammerdiener, M. D. Dettinger, J. M. Caprio, and D. H. Peterson (2001), Changes in the onset of spring in the Western United States, Bull. Am. Meteorol. Soc., 82(3), 399-415.

Cobourn, K., W. Xu, S. E. Lowe, and S. Mooney (2013), The effect of climate, weather, and water rights on land-allocation decisions in irrigated agriculture, Econ. Dep. working pap., Boise State Univ., Boise, Idaho.

Deschênes, O., and M. Greenstone (2007), The economic impacts of climate change: Evidence from agricultural output and random fluctuations in weather, Am. Econ. Rev., 97(1), 354-385.

Dettinger, M. D., and D. R. Cayan (1995), Large-scale atmospheric forcing of recent trends toward early snowmelt runoff in California, J. Clim., 8, 606-623.

Dittmer, K. (2013), Changing streamflow on Columbia basin tribal lands-Climate change and salmon, Clim. Change, 120, 627-641, doi: 10.1007/s10584-013-0745-0.

Elsner, M. M., L. Cuo, N. Voisin, J. Deems, A. F. Hamlet, J. A. Vano, K. E. B. Mickelson, S. Y. Lee, and D. P. Lettenmaier (2010), Implications of 21st century climate change for the hydrology of Washington State, Clim. Change, 102(1-2), 225-260.

Faux, J., and G. M. Perry (1999), Estimating irrigation water value using hedonic price analysis: A case study in Malheur County, Oregon, Land Econ., 75(3), 440-452.

Garrick, D., and B. Aylward (2012), Transaction costs and institutional performance in market-based environmental water allocation, Land Econ., 88(3), 536-560.

Hadjigeorgalis, E. (2009), A place for water markets: Performance and challenges, Appl. Econ. Perspect. Policy, 31(1), $50-67$.

$\mathrm{He}$, L., and T. M. Horbulyk (2010), Market-based policy instruments, irrigation water demand, and crop diversification in the Bow River Basin of Southern Alberta, Can. J. Agric. Econ., 58(2), 191-213.

Hutchins, W. A. (1968), The Idaho law of water rights, Idaho Law Rev., 5(1), 1-129.

Hutchins, W. A. (1977), Water Rights Laws in the Nineteen Western States, vol. III, Nat. Resour. Econ. Div., Econ. Res. Ser., U.S. Dep. of Agric., Washington, D. C.

Idaho Department of Water Resources (IDWR), Hydro Online. [Available at http://www.idwr.idaho.gov/hydro.online/gwl/default.html.]

Idaho Department of Water Resources (IDWR), Major River and Lake Layers. [Available at http://www.idwr.idaho.gov/Geographiclnfo/gisdata/hydrography.htm.]

Idaho Department of Water Resources (IDWR), Water Rights Place-of-Use Layers. [Available at http://www.idwr.idaho.gov/Geographiclnfo/ gisdata/water_rights.htm.]

Idaho Code, Title 42, Chapter 1, 2, 14 and 17; Title 55, Chapter 1.

Iglesias, E., A. Garrido, and A. Gómez-Ramos (2003), Evaluation of drought management in irrigated areas, Agric. Econ., 29(2), $211-229$.

IPCC (2007), Global climate projections, in Climate Change 2007: The Physical Science Basis. Contribution of Working Group I to the Fourth Assessment Report of the Intergovernmental Panel on Climate Change, edited by S. Solomon et al., Cambridge Univ. Press, Cambridge, U. K.

Kenny, J. F., N. L. Barber, S. S. Hutson, K. S. Linsey, J. K. Lovelace, and M. A. Maupin (2009), Estimated use of water in the United States in 2005, U.S. Geol. Surv. Circ. 1344, 52 pp.

Ko, J., L. R. Ahuja, S. A. Saseendran, T. R. Green, L. Ma, D. C. Nielsen, and C. L. Walthall (2012), Climate change impacts on dryland cropping systems in the Central Great Plains, USA, Clim. Change, 111(2), 445-472.

Luce, C. H., J. T. Abatzoglou, and Z. A. Holden (2013), The missing mountain water: Slower westerlies decrease orographic enhancement in the Pacific Northwest USA, Science, 342(6164), 1360-1364, doi:10.1126/science.1242335.

Mendelsohn, R., W. D. Nordhaus, and D. Shaw (1994), The impact of global warming on agriculture: A Ricardian analysis, Am. Econ. Rev., 84(4), 753-771. 
Mote, P. W. (2003a), Trends in snow water equivalent in the Pacific Northwest and their climatic causes, Geophys. Res. Lett., 30(12), 1601, doi:10.1029/2003GL017258.

Mote, P. W. (2003b), Trends in temperature and precipitation in the Pacific Northwest during the twentieth century, Northwest Sci., 77(4), 271-282.

Mote, P. W. (2006), Climate-driven variability and trends in mountain snowpack in Western North America, J. Clim., 19(23), 6209-6220.

Mote, P., and E. Salathé (2010), Future climate in the Pacific Northwest, Clim. Change, 102(1-2), 29-50.

Mote, P. W., A. F. Hamlet, M. P. Clark, and D. P. Lettenmaier (2005), Declining mountain snowpack in Western North America, Bull. Am. Meteorol. Soc., 86(1), 39-49.

Neumann, N. N., C. Derksen, C. Smith, and B. Goodison (2006), Characterizing local scale snow cover using point measurements during the winter season, Atmos. Ocean, 44(3), 257-269.

Peck, D. E., and R. M. Adams (2010), Farm-level impacts of prolonged drought: Is a multiyear event more than the sum of its parts?, Aust. J. Agric. Resour. Econ., 54(1), 43-60.

Pederson, G. T., S. T. Gray, C. A. Woodhouse, J. L. Betancourt, D. B. Fagre, J. S. Littell, E. Watson, B. H. Luckman, and L. J. Graumlich (2011), The unusual nature of recent snowpack declines in the North American Cordillera, Science, 333(6040), 332-335.

PRISM Climate Group, Oregon State University, Minimum and Maximum Temperature and Precipitation in April (from 1971 to 2000$)$, Corvallis, Oreg. [Available at http://prism.oregonstate.edu.]

Regonda, S. K., B. Rajagopalan, M. Clark, and J. Pitlick (2005), Seasonal cycle shifts in hydroclimatology over the Western United States, J. Clim., 18, 372-384.

Renshaw, E. F. (1958), Scientific appraisal, Natl. Tax J., 11(4), 314-322.

Robeson, S. M. (2004), Trends in time]-varying percentiles of daily minimum and maximum temperature over North America, Geophys. Res. Lett., 31, L04203, doi:1029/2003GL019019.

Schlenker, W., and M. J. Roberts (2009), Nonlinear temperature effects indicate severe damages to U.S. crop yields under climate change, Proc. Natl. Acad. Sci. U. S. A., 106(37), 15,594-15,598.

Schlenker, W., W. M. Hanemann, and A. C. Fisher (2005), Will U.S. agriculture really benefit from global warming? Accounting for irrigation in the hedonic approach, Am. Econ. Rev., 95(1), 395-406.

Schlenker, W., W. M. Hanemann, and A. C. Fisher (2006), The impact of global warming on U.S. agriculture: An econometric analysis of optimal growing conditions, Rev. Econ. Stat., 88(1), 113-125.

Schlenker, W., W. M. Hanemann, and A. C. Fisher (2007), Water availability, degree days, and the potential impact of climate change on irrigated agriculture in California, Clim. Change, 81(1), 19-38.

Stewart, I. T. (2009), Changes in snowpack and snowmelt runoff for key mountain regions, Hydrol. Processes, 23(1), 78-94.

Stewart, I. T., D. R. Cayan, and M. D. Dettinger (2004), Changes in snowmelt runoff timing in Western North America under a 'business as usual' climate change scenario, Clim. Change, 62(1-3), 217-232.

Stewart, I. T., D. R. Cayan, and M. D. Dettinger (2005), Changes towards earlier streamflow timing across Western North America, J. Clim., 18(8), 1136-1155.

The Constitution of the State of Idaho, Article XV, Sections 1-6.

Thompson, B. H., Jr. (1993), Institutional perspectives on water policy and markets, Calif. Law Rev., 81(3), 671-764.

U. S. Department of Agriculture, National Agricultural Statistics Service (USDA NASS), Cropland Data Layer (CDL), (2007-2011), USDA-NASS, Washington, D. C. [Available at http://www.nass.usda.gov/research/Cropland/Release/index.htm, last accessed 1 August 2012.]

U.S. Department of Agriculture, National Agricultural Statistics Service (USDA NASS), Quick Stats of Crops and Vegetables Price Received and Yield (2003-2010). [Available at http://quickstats.nass.usda.gov/, last accessed 1 August 2012.]

U. S. Department of Agricultural, Natural Resources Conservation Service (USDA NASS), Historic Monthly Adjusted Streamflow (1971 to 2000). [Available at http://www.nrcs.usda.gov/wps/portal/nrcs/main/id/snow/, last accessed 1 August 2012.]

U.S. Department of Agriculture, Natural Resources Conservation Service (USDA NASS), U.S. General Soil Map (STATSGO2). [Available at http://websoilsurvey.sc.egov.usda.gov/App/WebSoilSurvey.aspx, last accessed 1 August 2012.]

U. S. Department of Agriculture, Natural Resources Conservation Services (USDA NASS), Water Supply Outlook Reports (1992-2011). [Available at http://www.nrcs.usda.gov/wps/portal/nrcs/detail/id/snow/waterproducts/?cid=stelprdb1241057, last accessed 1 August 2012.]

U.S. Department of Commerce (USDC), U.S. Census Bureau (2010), Urbanized Areas. [Available at http://www2.census.gov/geo/tiger/ TIGER2010/UA/2010/, last accessed 9 December 2013.]

$\mathrm{Xu}, \mathrm{W}$. , and S. E. Lowe (2011), Value-oriented crop choices under natural and institutional risks of water shortage in irrigated land, Econ. Dep. Working Pap., Boise State Univ., Boise, Idaho. 